NBER WORKING PAPER SERIES

\title{
THE NATURE OF PRECAUTIONARY \\ WEALTH
}

Christopher D. Carroll

Andrew A. Samwick

Working Paper No. 5193

\author{
NATIONAL BUREAU OF ECONOMIC RESEARCH \\ 1050 Massachusetts Avenue \\ Cambridge, MA 02138 \\ July 1995
}

This work began while the second author was visiting the Board of Governors of the Federal Reserve System. The views expressed are those of the authors and do not necessarily represent those of the Board of Governors or the staff of the Federal Reserve System. We would like to thank Ronald Benabou, Olivier Blanchard, Angus Deaton, Martin Feldstein, Jon Gruber, Jerry Hausman, Charles Jones, Miles Kimball, James Poterba, Jonathan Skinner, William Wascher, David Wilcox, Stephen Zeldes, and seminar participants at the Federal Reserve, MIT, NBER, and American Economics Association 1993 Winter meetings for useful comments. Financial support from the National Science Foundation and the National Institute of Aging is gratefully acknowledged. This paper is part of NBER's research programs in Aging, Economic Fluctuations and Public Economics. Any opinions expressed are those of the authors and not those of the National Bureau of Economic Research.

(c) 1995 by Christopher D. Carroll and Andrew A. Samwick. All rights reserved. Short sections of text, not to exceed two paragraphs, may be quoted without explicit permission provided that full credit, including (-) notice, is given to the source. 


\title{
THE NATURE OF PRECAUTIONARY \\ WEALTH
}

\begin{abstract}
This paper uses the Panel Study of Income Dynamics to provide some of the first direct evidence that wealth is systematically higher for consumers with greater income uncertainty. However, the apparent pattern of precautionary saving is not consistent with a standard parameterization of the life cycle model in which consumers are patient enough to begin saving for retirement early in life: wealth is estimated to be less sensitive to uncertainty in permanent income than implied by that model. Instead, our results suggest that over most of their working lifetime, consumers behave in accordance with the "buffer-stock" models of saving described in Carroll (1992) or Deaton (1991), in which consumers hold wealth principally to insulate consumption against near term fluctuations in income.
\end{abstract}

Christopher D. Carroll

Mail Stop 80

Board of Governors of the Federal

Reserve System

20th and C Streets, NW

Washington, DC 20551
Andrew A. Samwick Department of Economics 6106 Rockefeller Hall Dartmouth College Hanover, NH 03755-3514 and NBER 


\section{Introduction}

Recent advances in the theory of precautionary saving, most notably by Kimball (1990a, 1990b, 1991), Zeldes (1989), and Caballero $(1990,1991)$ have sparked interest in whether precautionary saving is an empirically important phenomenon. This paper uses the Panel Study of Income Dynamics (PSID) to provide some of the first direct evidence that wealth is higher for households with greater income uncertainty. We also show, however, that the pattern of precautionary wealth holding does not appear to be consistent with a life cycle optimization problem in which retirement saving is important at early stages in life. Our empirical results are consistent with a version of the life cycle model like that in Carroll (1995), in which consumers engage in "buffer-stock" saving behavior during most of their working lifetimes and only begin to save for retirement around the age of 50 (or when retirement is approximately 15 years away).

Our empirical approach is to construct estimates of income uncertainty using the PSID and then to investigate the relationship between uncertainty and wealth. We first decompose income uncertainty into a variance of shocks to permanent (lifetime) income and a variance of shocks to transitory income. To be clear, an example of a shock to permanent income would be the experience of a unionized steel worker in the late 1970s whose expected future lifetime income was permanently reduced by the restructuring and de-unionization of the steel industry in that period. An example of a transitory shock might be lottery winnings, a bad crop for a farmer, lost wages due to a temporary illness, or any other change in income due to factors not expected to persist indefinitely. Controlling for demographic effects and for the level of income, our empirical results indicate that wealth holdings depend importantly on the degree of both transitory and permanent income uncertainty.

We then use the empirical results to discriminate between competing versions of the Life 
Cycle/Permanent Income Hypothesis (LC/PIH) model of consumption under uncertainty. We use numerical techniques to solve the life cycle problem under the parametric assumptions used by Hubbard, Skinner, and Zeldes (1994, henceforth HSZ) which imply that consumers begin saving for retirement early in life. We show that under the HSZ parametric assumptions, wealth holdings at every age should be highly sensitive to the degree of uncertainty in permanent income: the model predicts a regression coefficient on the variance of permanent shocks that is about an order of magnitude larger than the coefficients estimated in our empirical work.

Deaton (1991) and Carroll (1992) showed that if permanent income (infinite-horizon) consumers are more impatient ${ }^{1}$ than is typically assumed and do not borrow, they will engage in "buffer-stock" saving, holding a relatively small stock of assets whose primary purpose is to insulate consumption against near-term shocks to income. Carroll (1995) showed that even in a finite-horizon (life cycle) context, under plausible parametric assumptions consumers may spend a large part of their working lifetimes engaged in such buffer-stock saving behavior. We demonstrate in this paper that the sensitivity of wealth to uncertainty in permanent income is far lower for buffer-stock savers than for consumers engaged in retirement saving--sufficiently lower, in fact, to be consistent with our empirical estimates. The intuition for this result is that bufferstock savers have an effective "horizon" of only a few years (using "horizon" in the loose sense of Friedman (1957)), whereas consumers actively engaged in retirement saving have an effective horizon of the remainder of their lifetime. A negative shock to permanent income is viewed as a far more calamitous event for consumers with a long horizon than for consumers with a short

\footnotetext{
"The word "impatient" is used loosely here; all that is really needed is that, if income were certain, consumers would wish to borrow. A desire to borrow arises even among consumers with a low time preference rate as long as future income is expected to be higher than current income.
} 
horizon, so the retirement savers respond far more than do the buffer-stock savers to uncertainty in permanent income.

We also demonstrate that in a buffer-stock model of saving, wealth becomes less sensitive to permanent uncertainty as consumers become more impatient. With a higher time preference rate, the consumer's effective horizon is shorter, so a given amount of uncertainty in permanent income is of less consequence. We find that under the Carroll (1995) choices for parameters other than the rate of time preference, the buffer-stock model of saving can exactly match our empirical estimate for the sensitivity of wealth to permanent uncertainty if the rate of time preference is approximately 11 percent annually. (The two-standard-error band for the rate of time preference is from about 5 percent to almost 50 percent.)

The paper is organized as follows. In Section II, we discuss the various methods that others have used to study precautionary saving and then explain the relative merits of our approach. In Section III, we develop our technique for estimating the magnitude of permanent and transitory shocks to income and present these estimates by occupation, education, and industry group. The econometric results relating wealth holdings to income uncertainty are given in Section IV. We find evidence that consumers with higher variance of either permanent or transitory shocks to income hold more wealth. In Section V, we present the numerical solutions to the life cycle model with income uncertainty under the HSZ and the Carroll parameterizations, and we develop our methodology for estimating a time preference rate that enables the empirical results to discriminate between alternative theoretical frameworks. Section VI concludes. 


\section{Empirical Evidence on the Existence of Precautionary Saving}

The existing empirical literature on precautionary saving has found mixed results. In a widely cited early article, Skinner (1988) found the surprising result that saving is lower for groups thought to have higher income uncertainty. Using an Italian dataset in which consumers reported an expected distribution of income for the next year, Guiso, Jappelli, and Terlizzese (1992) found that consumption is only slightly lower and wealth only slightly higher for consumers with a greater subjective variance of next year's income. Dynan (1993) directly estimated the coefficient of relative prudence from household expenditure data and found it to be small and insignificantly different from zero. (In the absence of prudence, there is no precautionary motive for saving.)

Other studies have found evidence of a stronger precautionary saving motive. In an extension of Skinner's work, Dardanoni (1991) examined consumption and income data for British households and found that average consumption across occupation and industry groups is negatively related to the within-group variance of income. He estimated that around 60 percent of saving is due to precautionary motives. Carroll (1994) found that future income uncertainty is statistically significant and quantitatively important in regressions of current consumption on current income, future income, and uncertainty; his estimates suggest that a one standard deviation increase in income uncertainty decreases consumption between 2 and 5 percent. Finally, Carroll and Samwick (1995) estimated that about a third of household wealth is attributable to the fact that some households face greater income uncertainty than others.

An advantage of our approach over most of these previous studies is that all but Guiso, Jappelli, and Terlizzese (1992) and Carroll and Samwick (1995) relate uncertainty to current 
consumption rather than to the stock of wealth. The appropriate response to greater income uncertainty is to hold more wealth, but not necessarily to depress consumption forever. In the steady state of the buffer-stock model mentioned in the introduction, for instance, average consumption will approximately equal average income for both low and high uncertainty consumers, thus maintaining the average buffer stock constant at the optimal level for each group. Therefore, across consumers already holding the optimal buffer stock, there will be no apparent relation between current consumption and the uncertainty of income. However, consumers with greater uncertainty will desire a greater buffer stock, so there will be a relationship between the level of wealth and the degree of uncertainty. ${ }^{2}$

Measurement issues also militate for the use of wealth rather than consumption as the variable to be explained. The stock of wealth represents the household's response to all current and previous shocks to income, while current period consumption may be buffeted by a host of transitory factors that have little or nothing to do with fundamental saving decisions. We therefore suspect that current consumption is likely to be a noisier indicator of precautionary behavior than wealth holding.

A further criticism of the previous studies is that none used an entirely appropriate measure of income uncertainty. The models used by Guiso, Jappelli, and Terlizzese (1992) and Dardanoni (1991) imply that current consumption should depend on the degree of uncertainty in lifetime income. However, Guiso, Jappelli, and Terlizzese used the variance of households' own

\footnotetext{
${ }^{2}$ Until the optimal buffer stock is achieved there will be a relation between consumption and uncertainty--the consumer facing higher uncertainty will initially have to depress consumption more in order to build up the larger stock of wealth. But given the practical impossibility of determining which consumers are at the optimal buffer stock, the point remains that the relation between consumption and uncertainty is not clear.
} 
forecasts of income one year ahead; they impose strong assumptions to generate an estimate of lifetime uncertainty from this estimate of next year's variance. If the assumptions are incorrect, their measure of lifetime uncertainty could be seriously biased. Dardanoni's (1991) measure of uncertainty is even more troubling: he used within-group cross-sectional dispersion of income as the estimate for expected variance of lifetime income. There is no necessary relationship at all between this measure of dispersion and true uncertainty. In fact, for the standard set of eight occupation groups we use, the sample correlation in our PSID sample between our estimates of permanent uncertainty (which is essentially the measure required by Dardanoni's theory) and the group cross-sectional variances (the measure Dardanoni actually uses) is -0.50 . Carroll (1994) and Carroll and Samwick (1995) used utility-based measures of uncertainty derived, as are ours, from the PSID, but did not decompose the shocks into transitory and permanent components.

Using the panel dimension of income observations in the PSID, we are able to make direct estimates of the variance of innovations to permanent income for each household--the theoretically correct measure of uncertainty for the models used by Dardanoni (1991) and Guiso, Jappelli, and Terlizzese (1992). Furthermore, we can make a distinction between innovations to permanent income and transitory shocks to income that the more strictly utility-based measures used by Carroll (1994) and Carroll and Samwick (1995) do not distinguish.

\section{Estimating the Variances of Transitory and Permanent Shocks}

Our data set from the Panel Study of Income Dynamics contains income data for the years 1968 to 1989 for approximately 8,000 households. The PSID also contains data on household wealth in 1984. The goal of the empirical estimation is to determine how much of the variation in wealth across households in 1984 can be explained by differences in their income uncertainty. 
The first step is to quantify the degree of income uncertainty faced by each household. In this section, we define our measure of income and specify a parameterization for its predictable and uncertain components. We also present empirical estimates of income uncertainty by occupation, education, and industry group in the PSID and describe the consequences of measurement error and other data problems for our estimates of uncertainty.

The most natural way to link the PSID data to a model of precautionary saving is to identify the PSID "household" as the decision unit and to examine variability in household noncapital income. It is likely that the size of wealth holdings is chosen at the household level, and shocks to one individual's income may induce a change in the labor supply (and hence income) of other household members. Changes in household status, such as divorce or marriage, thus present a conceptual problem because it is difficult to know how to appropriately compare poststatus-change individual income to pre-change household income (or vice versa). To avoid these problems we restrict the sample to households that remained intact over the chosen sample period. According to our definition, a household remains intact whenever the same person is the head of household each year and the spouse, if present, is always the same person. We also impose other restrictions, described in detail in the Appendix, that reduce the amount of income variability in the sample due to factors other than income uncertainty, so that our results are not driven by a few outliers but by the general tendency of the data. A final restriction is that we use only data from 1981-1987, on the view that income uncertainty measures constructed using data from these years will correspond reasonably well to the true uncertainty for the midpoint year of 1984 , the year in which wealth is measured. ${ }^{3}$

\footnotetext{
${ }^{3}$ We also performed the analysis using data from $1976-1987$, with results similar to those we report.
} 
Our income measure, total household noncapital income, includes labor income of the head, spouse, and other household members; disability payments, welfare payments, and other forms of transfer income (including food stamps and in-kind transfers); unemployment insurance and Social Security payments; and almost all other kinds of income except direct capital income from assets like stocks, bonds, and real estate. For our purposes, this measure is preferable to the measure most commonly used in the labor economics literature, labor income of the household head, because the head's labor income may be implicitly insured by the spouse's income, by unemployment and disability benefits, and by a variety of other sources of income. Discretionary precautionary wealth holding should be motivated by the degree of income uncertainty after all these income insurance arrangements are taken into account. ${ }^{4}$

The assumptions necessary to decompose household income into transitory and permanent components are straightforward. ${ }^{5}$ The logarithm of permanent income $\mathrm{p}_{\mathrm{t}}$ is assumed to follow a random walk with drift:

$$
p_{t}=g_{t}+p_{t-1}+\eta_{t}
$$

where $g_{t}$ represents predictable growth due to life cycle aging and due to overall aggregate productivity growth and $\eta_{t}$ is the shock to permanent income in period $t$.

The log of current income is given by the log of permanent income plus a transitory error

\footnotetext{
${ }^{4}$ Ideally, income would be defined net of taxes as well as transfer payments because a progressive income tax structure reduces the variation in disposable income available to finance consumption (see Kimball and Mankiw (1989)). However, federal and state tax payments are not directly measured in the dataset and any tax schedule we could impose on actual data would introduce further (and perhaps substantial) measurement error.
}

${ }^{5}$ Our methodology here is a generalization of that of Hall and Mishkin (1982). 
term:

$$
y_{t}=p_{t}+\epsilon_{t}
$$

The errors $\varepsilon$ and $\eta$ are assumed to be white noise and uncorrelated with each other at all leads and lags. In order to remove the predictable component of income changes over time, $\mathrm{g}_{\mathrm{t}}$, we normalize observed income by dividing it by the predicted value from a regression of income on age, occupation, education, industry, household demographic variables, and interaction terms. ${ }^{6}$ The predicted values are also adjusted for economy-wide growth in income so that the average normalized income variable shows no trend over the sample period. Thus, equation (1) can be rewritten without the drift term $g_{t}$ as:

$$
p_{t}=p_{t-1}+\eta_{t}
$$

Define a d-year income difference as

$$
\begin{aligned}
r_{d} & =y_{t+d}-y_{t} \\
& =p_{t+d}+\epsilon_{t+d}-p_{t}-\epsilon_{t}
\end{aligned}
$$

where the second equality is obtained by substituting (2) into the first equality. Substituting (1') into (3) recursively yields

$$
r_{d}=\left\{\eta_{t+1}+\eta_{t+2}+\ldots+\eta_{t+d}\right\}+\epsilon_{t+d}-\epsilon_{t}
$$

Finally, we obtain the d-year variance as the second moment of the right hand side of

${ }^{6}$ Other sensible methods of removing the predictable changes in income produced results similar to those presented below. 
equation (4):

$$
\operatorname{Var}\left(r_{d}\right)=d \cdot \sigma_{\eta}^{2}+2 \cdot \sigma_{\epsilon}^{2}
$$

where $\sigma_{\eta}{ }^{2}$ and $\sigma_{\varepsilon}^{2}$ are the variances of the permanent and transitory shocks to income, respectively. Note that equation (5) makes use of the assumption that permanent and transitory shocks are white noise and uncorrelated with each other at all lags. We estimate $\operatorname{Var}\left(\mathbf{r}_{d}\right)$ for each household $i$ by $v_{i d}=r_{i d}{ }^{2}$, where $r_{i d}$ is constructed as in (3). This yields an unbiased estimate of $\operatorname{Var}\left(r_{i d}\right)$ if the mean of $r_{i d}$ is zero, which corresponds to an assumption that there are no individual-specific growth rates for income (other than those predictable by occupation, education, industry, and other personal characteristics). This assumption was tested for labor income of the household head in the PSID by MaCurdy (1982), who found it to be a good characterization of his data.

For each household, we can use any two $v_{d}$ 's of different lengths to solve for $\sigma_{\eta}^{2}$ and $\sigma_{\varepsilon}^{2}$. For example, for any $d>1$, one way of estimating $\sigma_{\eta}^{2}$ for a given household is simply to take (we suppress the subscript $i$ for clearer notation):

$$
s_{\eta}^{2}=v_{d}-v_{d-1}
$$

$$
s_{\epsilon}{ }^{2}=\frac{v_{d-1}-(d-1) \cdot s_{\eta}^{2}}{2}
$$

and it is easy to show that $\mathrm{E}\left(\mathrm{s}_{\varepsilon}{ }^{2}\right)=\sigma_{\varepsilon}{ }^{2}$. Our actual procedure for estimating $\sigma_{\varepsilon}{ }^{2}$ and $\sigma_{\eta}{ }^{2}$ is a generalization of this method; rather than only using two differences $v_{d}$ and $v_{d-1}$, we use a least squares projection to optimally combine differences constructed over the entire sample period. 
We use only those differences that guarantee that our estimate of the variance of the permanent innovation is robust to $\mathrm{MA}(2)$ serial correlation in the transitory component; this limits the differences used to those spanning three or more years. The methodology for this projection and the robustness to MA serial correlation are developed in the Appendix. ${ }^{7}$

Our decomposition of income shocks into permanent and transitory components is only one of many possible decompositions; Quah (1990) shows that with a finite data set it can be impossible to distinguish econometrically between a nonstationary series (as we assume) and a stationary series in which shocks have arbitrarily high persistence. If we were to characterize income as a stationary process, the implication would be that the displaced steel worker of the late 1970 s (or investment banker of the 1980s) would eventually regain a job in which wages were as high as before. We are skeptical that this is true; instead, it seems plausible that there are sometimes shocks to individuals' earnings profiles, positive and negative, that there is no reason to expect will ever be reversed.

The case for allowing a transitory component is also strong. Unemployment spells, bad harvests, gifts, temporary illness, and other transitory shocks to income are phenomena that undeniably exist and may be completely unrelated to innovations in permanent income. Some previous work has attempted to reduce the dimensionality of the income process by assuming that there is only one kind of shock which has both transitory and permanent components, but this assumption is both restrictive and, for our purposes, unnecessary. A final (and important) reason

\footnotetext{
${ }^{7}$ To be clear, "robustness against MA(2) serial correlation" means that equation (5) is the correct expression for the variance of a d-year income difference even if the transitory shock displays MA(1) or MA(2) serial correlation. Of course, if there is, say, $\mathrm{MA}(1)$ serial correlation of the form: $\varepsilon_{1}=\gamma_{1}+\theta \gamma_{1-1}$, then our estimate for the variance of the transitory innovation to income will be $\sigma_{e}{ }^{2}=\left(1+\theta^{2}\right) \sigma_{y}{ }^{2}>\sigma_{y}{ }^{2}$. However, we draw conclusions only from the sign, not from the magnitude, of the coefficients on transitory income variance below, so even if $\theta$ varied across households, our analysis would be unaffected.
} 
we specify the income process as we do is that the numerical solution to a life cycle model with uncertainty in Section $\mathrm{V}$ of the paper is considerably more tractable under this income process than under most alternatives.

Given that our decomposition procedure is robust to $\mathrm{MA}(2)$ correlation in the transitory innovation component (see the Appendix), the principal circumstance under which our methodology would be invalid is if transitory innovations to income (transitory in the sense of having no implications for income far in the future) had effects that lasted three years or longer. But MaCurdy (1982), Abowd and Card (1989), and others who have examined the labor income process found no evidence of serial correlation beyond $\mathrm{MA}(2)$ in the income innovations. Furthermore, we were unable to think of many examples of income shocks that are explicitly transitory but have effects that last longer than three years.

Table 1 presents our estimates of income uncertainty for the occupation, education, and industry groups we distinguish in the PSID. The first column presents an overall measure of income uncertainty over the 1981-1987 sample period: the square of the difference in (detrended) income between 1981 and 1987 , divided by six to have an annual measure. In our notation, this is equivalent to $r_{i 6}{ }^{2} / 6$. The comparisons across groups are much as we would expect. Farmers, Service Workers, and Self-Employed Managers have high uncertainty; Laborers, Clerical Workers, and Employed Managers have average uncertainty; Professionals and Craftsmen have the least uncertainty. For the $85 \%$ of the household heads with between nine years of education and a college degree, uncertainty declines with education. Among industry groups that comprise 10 percent or more of the sample, workers in the Manufacturing and Utilities sectors face less uncertainty than those in Trade or Professional Services. Additionally, workers in Public 
Administration face little income uncertainty.

The decomposition of income uncertainty into the variances of permanent and transitory shocks in the second and third columns is also informative. ${ }^{8}$ The sample average variances are 0.0217 and 0.0440 for the permanent and transitory components, corresponding to annual permanent shocks with a standard deviation of 14.5 percent of permanent income and annual transitory shocks with a standard deviation of 21.0 percent of permanent income. ${ }^{9}$ The importance of decomposing income variance into permanent and transitory components is clear in a comparison of Laborers to Service Workers. While the latter have a higher overall measure (when examined over a six year period), this is due to a very large variance of transitory shocks; the magnitude of permanent shocks is substantially higher for the Laborers (think again of the steel worker). Similar distinctions can be made by comparing Clerical/Sales Workers to SelfEmployed Managers and, among the industry groups, Manufacturing to Utilities. ${ }^{10}$

The decomposition for education groups suggests that the income process facing workers with the least education is large transitory fluctuations around a fairly predictable level of permanent income. This is consistent with a view that workers with little education earn

\footnotetext{
${ }^{8}$ As implied by equation (5), the first column of Table 1 is approximately equal to the sum of the second column and one-third of the third column.

${ }^{9}$ Although these figures may seem high, they are consistent with estimates obtained by MaCurdy (1982), Abowd and Card (1989), Hubbard, Skinner, and Zeldes (1994), and others. Of course, measurement error probably contributes something to the estimates; below we show that simple forms of measurement error should show up as additional transitory variance.

${ }^{10} \mathrm{As}$ demonstrated by the estimated transitory variance for workers in the Mining industry, the estimation procedure does not constrain the estimated variances to be non-negative in small samples, such as a household or an industry, even though the procedure is unbiased (see the discussion of the estimation procedure in the Appendix). An estimate that is negative but not significantly different from zero simply indicates that this group has a very low variance of the transitory shocks to income to which the estimate would converge if the sample size could be increased.
} 
predictably low wages (perhaps the minimum wage) and have intermittent attachment to the labor force. At higher levels of education, most of the reduction in the overall measure of uncertainty with greater education is in the transitory component until a college degree is obtained, at which point the variance of the permanent shocks drops. In general, the patterns presented for the overall and decomposed measures suggest that occupation, education, and industry are useful predictors of the degree of income uncertainty. It is important that occupation, education, and industry have explanatory power because these variables will subsequently be used as instruments for income uncertainty in our econometric analysis.

The estimates in Table 1 must be treated with some caution, because the underlying income data are undoubtedly subject to measurement error. However, because we intend to focus primarily on the coefficient on permanent uncertainty, measurement error may not cause important problems for our analysis. Suppose measurement error is of the commonly specified type:

$$
y_{t}^{r}=y_{t}^{\text {true }}+u_{t}
$$

where $y_{t}{ }^{r}$ signifies reported income and $y_{t}^{\text {tree }}$ signifies true income. Then if $u_{t}$ is white noise and the variance of the error term, $\operatorname{Var}\left(\mathrm{u}_{\mathrm{f}}\right)=\sigma_{\mathrm{u}}^{2}$, is uncorrelated with personal characteristics, measurement error will have no effect on our estimate of permanent uncertainty. This can be 
seen by noting that:

$$
\begin{aligned}
E\left(s_{\eta}{ }^{2}\right) & =\operatorname{Var}\left(r_{d}\right)-\operatorname{Var}\left(r_{d-1}\right) \\
& =d \cdot \sigma_{\eta}{ }^{2}+2 \cdot\left(\sigma_{\epsilon}{ }^{2}+\sigma_{u}{ }^{2}\right)-\left[(d-1) \cdot \sigma_{\eta}{ }^{2}+2 \cdot\left(\sigma_{\epsilon}{ }^{2}+\sigma_{u}{ }^{2}\right)\right] \\
& =\sigma_{\eta}{ }^{2}
\end{aligned}
$$

Equation (9) makes clear that measurement error in current income is treated by our procedure in the same way as transitory income shocks. Thus, the proof in the Appendix that our estimate of the permanent variance is robust to $\mathrm{MA}(2)$ serial correlation in the transitory shock also demonstrates that, in order for our estimate of permanent variance to be affected, the measurement error term would have to be more persistent than MA(2). Naturally, measurement error would increase our estimate of the level of transitory variance:

$$
E\left(s_{\epsilon}^{2}\right)=\sigma_{\epsilon}^{2}+\sigma_{u}^{2}
$$

but if $\sigma_{u}^{2}$ is the same for everyone the only effect of measurement error would be to raise the estimate of everyone's transitory variance by the same amount. The impact of such measurement error on the coefficients of the transitory variance term in the regressions we run is explored in the Appendix; we do not treat it here because the coefficient on the transitory variance term is not our principal interest.

One unfortunate property of our estimates of permanent and transitory variance is that they are negatively correlated across households. That is, households which are estimated to have high permanent uncertainty tend to have low estimates of transitory uncertainty. Although it may be the case that the true income process has some negative cross-correlation, this might also have been induced by the technique used to estimate the two components. Suppose now that 
$v_{\text {id }}$ is estimated with error, $v_{\text {id }}=v_{d}+z_{i}$, while $v_{i d-1}$ is measured without error. ${ }^{11}$ Then we will obtain (omitting the household subscript):

$$
\begin{gathered}
s_{\eta}{ }^{2}=v_{d}+z-v_{d-1} \\
=\sigma_{\eta}{ }^{2}+z \\
s_{\epsilon}^{2}=\frac{\left[v_{d-1}-(d-1) \cdot s_{\eta}{ }^{2}\right]}{2} \\
=\frac{\left[v_{d-1}-(d-1) \cdot\left(\sigma_{\eta}{ }^{2}+z\right)\right]}{2} \\
=\sigma_{\epsilon}{ }^{2}-\frac{(d-1) \cdot z}{2}
\end{gathered}
$$

So even if $\operatorname{Cov}\left(\sigma_{\eta}^{2}, \sigma_{\varepsilon}^{2}\right)=0, \operatorname{Cov}\left(s_{\eta}{ }^{2}, s_{\varepsilon}^{2}\right)=-(d-1) \sigma_{z}^{2} / 2<0$. Although this may be a substantial problem at the level of the individual household, the Appendix shows that the spurious negative correlation diminishes when the correlation is taken among aggregates of households such as occupation, education, or industry groups. Given a large enough sample for each group, the spurious negative correlation would disappear completely as the estimates of the group v's approached their true values. In fact, across the groupings presented in Table 1 , the correlation coefficient is -0.016 , compared to the -0.819 which obtains at the household level.

\section{How Does Wealth Depend on Uncertainty?}

Having constructed our measures of income uncertainty to be used as explanatory variables, we now turn to the measure of wealth and the econometric specification linking the two. Unfortunately, for reasons of tractability, theories of saving under income uncertainty

\footnotetext{
"Note that this is a different issue from the income measurement error just discussed. Measurement error in income would cause the same measurement error in $v_{1 d}$ and $v_{\text {id-1 }}$, and would therefore cancel out; here we are supposing that $v_{\text {id }}$ and $v_{\text {id-1 }}$ are mismeasured by different amounts.
} 
typically consider only a single, perfectly liquid, asset. In reality, of course, there are many types of assets which differ in the degree of liquidity and other attributes.

Because theory gives us little guidance about what the appropriate measure of wealth for an econometric study may be, we will consider three measures of wealth in our empirical estimates. Very liquid assets (VLA) are those assets which could be liquidated immediately: bank account balances, money market funds, certificates of deposit, government savings bonds, mutual funds, and publicly traded stocks. Non-housing, non-business wealth (NHNBW) adds to VLA the net value of all other assets and liabilities not related to the primary residence or personally owned businesses. Such assets include non-government bonds, the cash value of whole life insurance, cars and other vehicles, secondary real estate, and other investments. In addition to loans or mortgages on any of these assets, NHNBW also deducts the balances on credit cards, student loans, outstanding medical and legal bills, and loans from relatives. Most of the components of this measure could be liquidated (or at least have the amount of equity altered) within a matter of weeks or months. Finally, total net worth (NW) adds to NHNBW what are generally the most illiquid assets owned by households: equity in the primary residence and the net value of personally owned businesses.

A priori, none of the three wealth measures is clearly superior to the others. If we chose to focus only on very liquid assets, and consumers, for example, put their precautionary savings into less liquid assets or responded to uncertainty by holding less debt, we could erroneously conclude that no precautionary saving existed. This possibility suggests using the most inclusive wealth measure, total net worth, as the dependent variable. However, some illiquid assets may be held primarily for reasons that have nothing to do with uncertainty. Home equity, for 
instance, may be accumulated because of the considerable tax advantages to homeownership. The comparatively large transactions costs associated with readjusting the stock of housing suggest that housing assets would be an inconvenient vehicle for insulating consumption against transitory income fluctuations or small fluctuations in permanent income. ${ }^{12}$ On the other hand, housing equity might be an ideal asset to self-insure against low-probability but truly catastrophic shocks: if disaster occurs, the liquidation costs might be small relative to the liquidation value of the asset, but if the disaster never arises, investment in housing earns a handsome after-tax rate of return.

Means and medians of the three measures of wealth, and of their ratios to estimated permanent income, are presented in Table 2, along with analogous measures constructed using a comprable sample from the Survey of Consumer Finances 1983 of the Federal Reserve Board. ${ }^{13}$ The SCF results are presented in order to verify that our PSID sample, even after making all of our various sample restrictions, at least roughly approximates the true wealth holding patterns in the U.S. in 1983. If the two surveys had substantially different distributions for wealth, then there would be reason to believe either that the sample might not be representative of the population ${ }^{14}$ or that the PSID measures of wealth were flawed. Only in the case of the level of VLA, however, is the median wealth substantially different across the surveys (19\% lower in

\footnotetext{
${ }^{12}$ As shown by Eugeni (1993), housing equity has become more liquid since the end of our sample period due to the growing use of home equity loans and lines of credit to finance consumption expenditures.

${ }^{13}$ Because of the limited data on income in the SCF, our definition of permanent income for the purpose of comparing wealth-to-income ratios across surveys is simply the income that is predicted by our wage equation. This (in logarithms) corresponds approximately to the definition of $p_{t}$ in equation (1).

${ }^{14}$ Our PSID sample is limited to households related to the original non-poverty sample in the 1968 PSID. A host of factors could have caused the sample to evolve in non-random ways since 1968 . We wish to demonstrate here only that the sample means and medians do not appear to have drifted too far from population statistics; demographic data were also quite similar in our sample and the SCF.
} 
$\mathrm{SCF})$; at all other medians, the wealth values are within 6 percent across surveys.

When measured at means, NHNBW is the closest measure across surveys, being six percent higher in the PSID in levels and five percent lower as a ratio to permanent income. ${ }^{15}$ The mean values in the PSID are 30 percent lower for VLA and 19 percent lower for NW. That this discrepancy is not present for NHNBW or when measured at medians suggests that it is the result of the concentration of some assets (such as publicly traded stock in VLA and personal businesses in NW) in the top few percentiles of the wealth distribution. ${ }^{16}$ (The SCF better reflects the average holdings of assets whose distributions are highly skewed, because the SCF survey design intentionally oversamples the wealthy). When the high-income sample is excluded from the SCF data, these discrepancies are much less apparent. ${ }^{17}$ Because of the skewness of the actual wealth distribution, we estimate the econometric specification in logs to alleviate any effect of poor measurement at the top of the distribution on our results.

With measures of wealth and uncertainty in hand, the next step is to regress household wealth on uncertainty in our sample of households. However, at the level of the individual

\footnotetext{
${ }^{15} \mathrm{Here}$ we identify permanent income as the level of income predicted by the age, occupation, education, industry, and demographic variables used elsewhere in the paper.

${ }^{16}$ We present results for the sample in which the head of household is fifty years old or younger because this is the sample we will use in our econometric work. This age restriction is chosen because the alternative parameterizations of the life cycle models in Section $V$ have sharply different implications below that age, but are more difficult to compare in the immediate pre-retirement period. We also exclude households which did not hold strictly positive amounts of the relevant wealth measure because the skewness of the underlying wealth distributions suggests an econometric specification in logs (which cannot be computed for nonpositive values). The observed differences between the two surveys are smaller when the sample includes the older households and those with zero or negative wealth holdings.

${ }^{17}$ Our tabulations are consistent with those of Curtin, Juster, and Morgan (1989) who carefully compared the SCF and the PSID and concluded that the PSID provided nearly as good a measure of wealth as the SCF for most of the population, although the SCF is far superior for examining the behavior of the wealthiest families. Avery, Elliehausen, and Canner $(1984 a, b)$ discuss the correspondence between the $1983 \mathrm{SCF}$ and other sources of wealth data such as the Flow of Funds accounts.
} 
household our direct measures of the variance of transitory and permanent shocks to income will be subject to substantial measurement error: equations (7) and (8) show that in expectation our measures of uncertainty correspond to the true measures of uncertainty, but for any individual household our measures are a noisy approximation to the actual uncertainty faced because our method essentially estimates two parameters of the household income process from seven income observations for that household. For a given household, our estimates of the variances can be represented as the true variances plus some household-specific error term. This is a standard example of the errors-in-variables problem, so if we were to estimate an ordinary least squares regression of wealth on our constructed measures of household uncertainty, the estimated coefficients on the uncertainty terms would be attenuated toward zero with the magnitude of the bias proportional to the variance of the household-level measurement error. Since at the household level the variance of the error must be considerable, the coefficients from an OLS regression would be severely biased. ${ }^{18}$ We adopt the standard solution to such errors-in-variables problems, which is to estimate the equation using instrumental variables.

Because the life cycle model implies that wealth is also influenced by factors other than uncertainty, the regressions include demographic variables and a measure of household permanent income. The regressions are therefore of the form:

$$
\log (W)=\alpha_{0}+\alpha_{1} s_{\eta}^{2}+\alpha_{2} s_{\epsilon}^{2}+\alpha_{3} \log (P)+X \beta+\varepsilon
$$

where $P$ is an estimate of permanent income (defined here to be the average household income over the sample period) and $\mathbf{X}$ contains age and other demographic variables to control for

\footnotetext{
${ }^{18}$ In the OLS regressions we estimated, the coefficients on the uncertainty terms were in fact smaller and less statistically significant than in the instrumental variables specification.
} 
(predictable) life cycle effects on wealth. The use of the logarithm of wealth is motivated by the skewness of the wealth distribution observed in Table 2.

In order to estimate this equation we must decide which variables to use as instruments for the income and uncertainty terms and which to include in our demographic variables $\mathbf{X}$; to achieve identification, the instrument set must include variables that are not also in $\mathbf{X}$. Our choice was to define $\mathbf{X}$ to include age, marital status, race, sex, and the number of children in the household but to exclude occupation, education, and industry variables from $\mathbf{X}$ in order to identify the model. These variables will be valid instruments only if, first, they have predictive power for income and uncertainty and, second, they have no predictive power for wealth beyond their influence through their ability to predict income and uncertainty. Table 1 provides some evidence that the first condition is satisfied. More formally, Bound, Jaeger, and Baker (1993) suggest the use of the partial $\mathrm{R}^{2}$ and F-statistic on the excluded instruments in the first stage regression be used as rough guides to the quality of the IV estimates. The partial $R^{2}$ of the excluded instruments in the first stage regressions are 0.106 for the variance of permanent shocks and 0.078 for the variance of transitory shocks. The p-values for the F-test of joint significance of the instruments are 0.0001 and 0.0379 , respectively. ${ }^{19}$ Thus, our estimates of equation (14) should not suffer from the econometric problems first highlighted by Nelson and Startz (1990a, b) that can occur when the first-stage regressions perform poorly. ${ }^{20}$

\footnotetext{
${ }^{19}$ These statistics correspond to the sample comprised of observations that report valid data for NHNBW. The VLA sample yielded partial $R^{2}$ of 0.0847 and 0.0732 and p-values of 0.0062 and 0.0488 for permanent and transitory variances, respectively. For the NW sample, the statistics were $0.1066,0.0691,0.0007$, and 0.1086 .

${ }^{20}$ See Staiger and Stock (1994) for an analysis of the effect of weak instruments on the second stage regression results. The test of instrument relevance based on the canonical correlations of the instrument set proposed by Hall, Rudebusch, and Wilcox (1994) also rejected the null hypothesis for each sample with p-values below 0.001 .
} 
The second stage regression results for equation (13) are presented in Table 3 for the sample of households fifty years old or less for each of the three measures of wealth. ${ }^{21}$ Because Breusch-Pagan and Goldfeld-Quandt tests rejected the null hypothesis of homoskedasticity at the 5 percent level or below, the standard errors reported for each coefficient are heteroskedasticityrobust. The key result is that for all three measures of wealth, the variances of both permanent and transitory shocks to income have positive effects on wealth holding. These estimates are significantly different from zero at the 1 percent (permanent) and 5 percent (transitory) levels for all three measures of wealth, providing evidence of precautionary saving. The effect of uncertainty on wealth declines as the measure of wealth becomes more comprehensive (and less liquid), with the drop in the effect of transitory shocks between VLA and NHNBW being larger. Using the coefficients for NHNBW to compute the marginal effects of uncertainty on wealth, increasing the annual standard deviation of the permanent shock from 5 percent to 10 percent increases wealth by 7.1 percent; increasing it from 10 percent to 15 percent increases wealth by 11.8 percent. The corresponding effects of an increase in the variance of the transitory shock are 2.9 percent and 4.8 percent, respectively.

The effects of the other explanatory variables in the regressions are plausible. There is a positive relationship between wealth and permanent income which declines in magnitude as the measure of wealth becomes more comprehensive; a one percent change in permanent income increases holdings of VLA by 3 percent but NW by only 1.6 percent. (This is consistent with the stylized fact that the wealthiest households hold their wealth disproportionately in equities

\footnotetext{
${ }^{21}$ We restrict the sample to those younger than fifty because the theoretical results presented below, and in Carroll (1995), suggest that the behavior of households younger than about 50 may be qualitatively different from the behavior of those older than 50 . For details, see the theoretical analysis below.
} 
and other liquid forms.) An increase in age has a positive effect on wealth levels that decreases in magnitude with age. The race of the head of household has a significant effect on total net worth, but the sex of the head does not (controlling for income). Other things equal, if the head is married, very liquid assets are about 50 percent lower but total net worth is about 50 percent higher, reflecting that married households are more likely to hold their wealth in the form of housing. Additional children under 18 in the household reduce wealth levels, but the effect is not significant for total net worth.

Our instrumental variables estimation procedure implicitly assumes that our instruments (occupation, education, and industry) are correlated with wealth holding only insofar as they are correlated with the variables for which we are instrumenting, uncertainty and permanent income. The validity of this assumption is tested by considering the instrumental variables regressions in a generalized method of moments framework and using the heteroskedasticity-robust test of the overidentifying restrictions given in Hansen (1982). The p-values are reported at the bottom of the table. For VLA and NHNBW, the p-values are not small enough to reject the specification, but the p-value of 0.0750 for NW suggests that the occupation, education, or industry variables may have a direct effect on total net worth..$^{22,23}$

\footnotetext{
${ }^{22}$ Despite these favorable OID tests, it of course remains possible that our instruments are related to wealth through channels other than their correlation with uncertainty and income. We chose occupation, education, and industry as our instruments primarily because these are the variables used in previous work on the relationship of consumption to income and income growth (Carroll (1994), Carroll and Weil (1994)). A thorough search of the dataset for other variables that, a priori, we might have thought would be related to uncertainty found no variables that were able to explain much of the variation in uncertainty beyond that explained by occupation, education, and industry.

${ }^{23}$ If occupation group is added to the $\mathbf{X}$ variables, the overidentification restriction for $\mathrm{NW}$ is no longer rejected; the coefficients on the income uncertainty terms are reduced but are not significantly different (at the 5 percent level) from those reported in Table 3. However, the coefficients on the uncertainty terms for NW are no longer statistically significantly different from zero. Alternatively, if households in which the head is over age $\mathbf{4 5}$ are excluded from the sample, the p-value on the overidentification test rises to 0.20 and the coefficients are slightly lower ( 7.74 and
} 
A remaining caveat with the estimates in Table 3 is that, because wealth is measured in logs, households for whom reported net worth is negative (approximately 10 percent of the sample) have been omitted. In order to determine whether the bias from this censoring is empirically important, we estimated two-stage Heckit models in which the inverse Mills ratio from a probit of whether or not the observation reported strictly positive wealth was included as a regressor in the second stage regression. ${ }^{24}$ For each measure of wealth, the estimated coefficients on the uncertainty variables are not statistically different from the estimates in Table 3 and are still significantly different from zero at the 1 percent (permanent) and 5 percent (transitory) levels. For example, the coefficients in the NHNBW regression are 8.78 and 3.81 for permanent and transitory variances, respectively, compared to 9.43 and 3.88 in Table 3 .

\section{Simulated Results from a Buffer-Stock Model of Saving}

We now wish to determine whether the results of Table 3 showing that wealth is positively and significantly related to income uncertainty are consistent with existing theories of precautionary saving. Our method for answering this question is to solve a standard life cycle model with a precautionary saving motive and to determine what coefficients it would predict on $\sigma_{\eta}{ }^{2}$ and $\sigma_{\varepsilon}{ }^{2}$ when estimating an equation like (14). In practice, dynamic programming problems of this nature are quite complicated. As Zeldes (1989) and others have noted, analytical solutions do not exist for the most plausible class of precautionary saving models, those

3.47 for permanent and transitory, respectively) and statistically significant at the same levels as in Table 3 . These two findings suggest that differences in the retirement prospects facing workers across different occupations may be affecting non-precautionary saving for the part of the sample closest to retirement. See the discussion in Section V (of Figure 4 in particular).

\footnotetext{
${ }^{24}$ The explanatory variables in the probit were identical to that in the first stage regression for instrumental variables. Using the predicted values of the income and uncertainty variables (rather than the full set of instruments) in the first stage did not affect the second stage regression estimates, as we would expect from the failure of the OID test to reject.
} 
with Constant Relative Risk Aversion utility and general forms of uncertainty. We will therefore solve such a model using numerical methods. The model of consumer behavior, which is similar to that in Carroll (1995) and also to that of Zeldes (1989) and Hubbard, Skinner, and Zeldes (1994), is given by:

$$
\begin{aligned}
\max _{\left\{C_{t}\right\}} & E_{s} \sum_{t=s}^{T} \beta^{t-s} u\left(C_{t}\right) \\
\text { s.t. } & \\
X_{t+1} & =R\left[X_{t}-C_{t}\right] \\
Y_{t} & =P_{t} V_{t} \\
P_{t+1} & =G P_{t} N_{t+1}
\end{aligned}
$$

where gross wealth (what Deaton (1991) calls cash-on-hand) is $X_{t}=W_{t}+Y_{v}$ the sum of net wealth and current labor income (i.e. non-capital income, as discussed above); current labor income $Y_{t}$ is given by permanent labor income $P_{t}$ multiplied by a random mean-one transitory error $V_{t}$; permanent labor income $P_{t}$ is equal to last period's permanent labor income multiplied by a random mean-one error $N_{t}$; the time preference factor is $\beta=1 /(1+\delta)$ where $\delta$ is the time preference rate; and the utility function is of the CRRA form $u(c)=c^{(1-\rho)} /(1-\rho)$, where $\rho$ is the coefficient of relative risk aversion. The structure of the income uncertainty follows Zeldes (1989) and Carroll (1995): The multiplicative transitory shock to income, $V_{t}$, is zero with probability $\pi$, corresponding to periods of unemployment when income is zero. ${ }^{25}$ If $V_{t}$ is not

\footnotetext{
${ }^{25}$ Including a positive probability of zero-income events has the effect of preventing consumers from borrowing. They voluntarily choose not to borrow because, if there is a positive probability of zero income events in each period, borrowing any finite sum induces a positive probability that consumption will be driven to zero in some future period (if enough bad income draws in a row arrive). With CRRA utility, zero consumption results in infinitely negative utility. For readers uncomfortable with this logic, it may be easier to justify the zero-probability events as an alternative way to effectively put liquidity constraints in the model without introducing the additional computational difficulties associated with a kinked marginal utility function or consumption rule. For further discussion of these issues, see Zeldes (1989) or Carroll (1995).
} 
zero, it is distributed lognormally. We assume that $N_{t}$, the multiplicative shock to permanent income, is also distributed lognormally, so that the log of permanent income follows a random walk with drift.

We begin by solving the model using a set of parameter values based on those used by Hubbard, Skinner, and Zeldes (1994). They assumed an interest rate equal to the time preference rate at 3 percent annually; a coefficient of relative risk aversion $\rho=3$; and a median age-income profile that can be approximated by one in which (real) income grows at around 2 percent annually until age 55, then declines at about 1 percent annually until retirement at age 65 . At retirement, income drops to about 70 percent of its immediate pre-retirement level and remains constant thereafter.

HSZ characterized the stochastic process for income as an AR(1) with a coefficient of 0.95 on lagged income, whereas our specification assumes that the log of permanent income has a unit root. We prefer our characterization for the reasons cited in Section III when this issue arose in the empirical decomposition of income shocks: we find the intuitive case for both transitory and permanent shocks to income to be compelling. Furthermore, the model with the AR(1) specification is much more difficult to solve numerically. HSZ estimate that the standard deviation of the innovations to their income process is around 0.095 ; this is the analog in their estimation to the variance of $\log (\mathrm{N})$ in our model. For simplicity, we will identify $\sigma_{\eta}=0.1$ as the HSZ parameter value. We also set $\sigma_{\varepsilon}=0.1$ for the transitory shock. This is also consistent with the assumption in Carroll (1992, 1993).

The model is solved using standard numerical recursive dynamic stochastic programming 
methods. ${ }^{26}$ The optimal consumption rule can be expressed as a function of the gross-wealth-topermanent-income ratio $\mathrm{X} / \mathrm{P}$ (henceforth, the gross wealth ratio). Defining lower-case letters as their upper-case values normalized by permanent income, the optimal consumption rule in the last period of life is given by $c_{\mathrm{T}}\left(\mathrm{x}_{\mathrm{T}}\right)$. Given the optimal rule in the last period of life, the model can be solved numerically for the optimal rule in the second-to-last period of life, $c_{\mathrm{T}-1}\left(\mathrm{x}_{\mathrm{T}-1}\right)$, and so on back to the first period of life (in our model, this is age 21).

Once the model has been solved to obtain optimal consumption rules for each age of life, the wealth distribution, $\left\{\mathrm{W}_{\mathrm{t}}\right\}$, of a population of consumers who behave according to those rules can be simulated. Starting with no assets in the first year of life, each consumer draws randomly from our assumed distributions for transitory and permanent shocks to income, and income is constructed using random draws that follow the stochastic process described above. The consumer applies the optimal consumption rule for the first period of life, and this determines the savings that are carried over into the second period of life. Income shocks are then drawn for the second period, determining second-period consumption and saving carried into the third period. This process is repeated for the entire lifetime for a large number of households $(10,000)$.

The results from solving and simulating the model under the HSZ parameter values are given by the solid line in Figure 1, which shows mean values for the ratio of net wealth to permanent labor income (henceforth, the net wealth ratio) by age. HSZ consumers begin saving for retirement early in life and build up a large stock of assets over the course of a lifetime of

\footnotetext{
${ }^{26}$ The solution method is presented in detail in Carroll $(1992,1993)$.
} 
saving. ${ }^{27}$ These assets are then depleted after retirement, and consumers end life with zero assets. The dashed line shows how the results change when the assumption about the standard deviation of the annual shock to permanent income is reduced from the HSZ baseline value of 0.1 to a value of 0.05 . The effect on wealth accumulation is dramatic: wealth is much lower over the entire working lifetime.

The experiment just performed provides a way to approximate the coefficient that the model would predict in regressions like those estimated above. Consider a consumer at age 30. Under the baseline HSZ parameter values with $\sigma_{\eta}=0.1$, the predicted mean net wealth ratio is 1.473. Under the alternative with $\sigma_{\eta}=0.05$ and with all other parameter values the same, the predicted wealth ratio at 30 is 0.424 . Hence, the coefficient on a regression of $\log (\mathrm{W})$ on $\sigma_{\eta}{ }^{2}$ would yield a coefficient that can be approximated by $[\log (1.473)-\log (0.424)] /\left(0.1^{2}-0.05^{2}\right) \approx$ 166.

The coefficients predicted by the model using the HSZ parameter values can be estimated in the same way for each age of life; the results are shown in Figure $2 .^{28}$ From an analytical perspective, an inconvenient feature of the results is that the predicted coefficient on $\sigma_{\eta}{ }^{2}$ is quite different at different ages. Due to the limited size of our empirical sample we were not able to estimate age-specific coefficients on $\sigma_{\eta}{ }^{2}$ that differed significantly from each other. However, it is clear from this figure that even had we been able to estimate age-specific coefficients they

\footnotetext{
${ }^{27}$ The sharp increase in the graph at age 65 is due to the revaluation of permanent income to 70 percent of its pre-retirement level, thereby increasing the ratio of net wealth to permanent income for the given stock of net wealth accumulated during the working years.

${ }^{28}$ The upturn in the last couple of years of life represents consumption of the precautionary assets that are no longer needed because there is no future to save for. If we were to complicate the model slightly by having a steadily increasing mortality probability until certain death at, say, age 120 , this upturn would be eliminated. Experimentation with such models suggested to us that they provide little additional insight for the question at hand, so we preferred to leave the model as simple as possible by keeping the date of death certain.
} 
would not have been consistent with this model: between the ages of 25 and 50 the predicted coefficient on $\sigma_{\eta}{ }^{2}$ from the HSZ model averages over 100, whereas our empirical estimates of the coefficient on $\sigma_{\eta}{ }^{2}$ for households younger than 50 ranged only from 8.6 to 12.1 , depending on the measure of wealth. It is apparent that, at least under the HSZ parameter values, the model is strongly inconsistent with our empirical estimates.

It is worth noting here just how overwhelming is the magnitude of the rejection of the model under the HSZ parameter values. Even if our estimated standard errors had been three times as big, we would still have been able to reject a coefficient of 100 on the permanent variance term with an enormous degree of statistical significance.

Deaton (1991) provides an insight into why the HSZ model implies such extraordinarily high responsiveness of wealth accumulation to the degree of uncertainty in permanent income. Deaton showed, using an infinite-horizon model where income was expected to grow at rate $\mathrm{g}$ indefinitely, that the successive consumption-to-permanent-income rules $c_{T}[x], c_{T-1}[x], \ldots$ converge to a fixed rule $c^{*}[x]$ if the following condition is satisfied:

$$
\rho^{-1}(r-\delta)+\frac{\rho}{2} \sigma_{n}^{2}<g
$$

The intuition for this equation comes from noting that, if there is no uncertainty, the desired rate of growth of consumption in a CRRA model is $\rho^{-1}(r-\delta)$. Consider a consumer with zero physical assets. If the growth rate of consumption $\rho^{-1}(r-\delta)$ is lower than the growth rate of income $g$, but the intertemporal budget constraint is balanced so that the present discounted value of consumption and income are the same, it must be the case that the level of consumption is higher than the level of income; that is, a consumer with perfectly certain income would wish to borrow 
against future income to finance current consumption. Thus the equation above amounts to an assumption that consumers are "impatient" in the sense that, if there were no uncertainty, they would wish to borrow (or, if they have assets, run them down).

The reason this condition is necessary for a solution to the infinite-horizon version of the model can be understood by considering what happens if the condition is not satisfied. In that case, consumers are "patient," in the sense that, whatever is their current level of wealth, they will spend less than their income and therefore add to wealth. In this case infinite-horizon consumers will accumulate wealth without bound. Summers (1982) noted that in a certainty model of this kind the long-run interest elasticity of wealth is infinite, because at a higher interest rate consumers will accumulate wealth faster forever, and thus the gap between the amount of wealth that would be accumulated at one interest rate and the amount that would be accumulated at another interest rate grows without bound over time. Analogously, in the infinite-horizon model with uncertainty, if the Deaton condition is not satisfied the long-run elasticity of wealth with respect to the degree of permanent income uncertainty should also be infinite (assuming a partial-equilibrium context).

This provides an intuition for why the elasticities in the HSZ parameterization of the life cycle model are so high: their parametric choices come close to failing the Deaton condition. For their choices of $\rho=3, r=\delta=0.03$, and $\sigma_{\eta}=0.10$, the left-hand side of equation (15) is $\rho^{-1}(\mathrm{r}-\delta)=0+\rho / 2 \sigma_{\eta}^{2}=0+3 / 2(0.01)=0.015$. It is a bit difficult to know what income growth rate to compare this to, because in the finite-horizon context the income process is not summarized by a single growth rate. However, the average growth rate from ages 25 to 65 under HSZ parameter values is close to 1.5 percent a year, and at age 65 income plunges to 70 percent 
of its pre-retirement level, so it is clear that their parametric choices are at least on the borderline of failing to satisfy the Deaton condition. Of course, in a finite-horizon context wealth cannot be infinitely responsive to the degree of uncertainty as it is in the limit of an infinite-horizon model, but Figure 2 shows that under the HSZ parameter values wealth can be remarkably sensitive to the degree of permanent uncertainty even in a finite-horizon model.

The foregoing argument suggests that the failure of the model under HSZ parameter values is a direct result of parametric assumptions which either fail, or come close to failing, the Deaton condition. It is therefore worth considering whether other plausible parametric assumptions can generate results more consistent with our empirical results. Under an alternative set of parameter values similar to those used in Carroll (1995), the model does indeed produce results that are much more consistent with our empirical findings.

The most important difference between our alternative parameter values and the HSZ parameter values is in the age-income profile. Using our PSID data we estimate empirical agespecific income growth rates that are uniformly from 1 to 2 percentage points greater at every age than those found by HSZ: we estimate that income grows, on average, at roughly 3 percent a year from age 25 to age 55 and at 1 percent a year from age 55 to 65 . This discrepancy arises because the HSZ age-income profiles were made from cross-section data that did not incorporate the portion of household income growth attributable to a generally rising level of productivity in the economy. We see no reason to exclude the effects of this important component of income growth from the age-income profile.

Another HSZ parametric choice that can be questioned is the real interest rate of 3 percent annually. The asset in the model is perfectly riskless and perfectly liquid. The closest real-world 
analogue to such an asset is probably short-term T-bills. The after-tax real rate of return on 3 month T-bills in the postwar period has been close to 0 percent annually, so our baseline interest rate will be 0 . HSZ also assume a time preference rate of 3 percent annually; we will follow much of the macroeconomics literature in choosing a baseline time preference rate of one percent per quarter or 4 percent a year. ${ }^{29}$

A final difference is that HSZ do not explicitly model the possibility that there may be periods when income goes to zero. However, Carroll (1992) found that annual income was approximately zero roughly 0.5 percent of the time for his sample of PSID households. These "zero-income events" were usually associated with a spell of unemployment, a job change, or an illness. ${ }^{30}$ In a model of precautionary saving it seems inappropriate to exclude such events from the stochastic specification of income, so we adopt the Carroll (1992) estimate that zero-income events happen with annual probability 0.5 percent. As discussed above, even in the absence of liquidity constraints, this assumption guarantees that our consumers will never choose to borrow, because if they were to borrow and then earned zero income they might have to consume zero, which yields negative infinite utility under a CRRA utility specification. HSZ impose a liquidity constraint directly.

\footnotetext{
${ }^{29} \mathrm{HSZ}$ also carefully model the social welfare system in the United States with the aim of explaining the behavior of households at the bottom of the income distribution. They conclude that these households should hold zero wealth because the disincentives to wealth holding are very strong when transfer payments are means-tested. This issue is more fully described in Hubbard, Skinner, and Zeldes (1995). We did not attempt to duplicate the impressively complex detail their model includes for the bottom of the income distribution because we are primarily interested in the behavior of those who hold some wealth, rather than those at the very bottom who hold none.

${ }^{30}$ The measure of income used was inclusive of unemployment insurance, disability payments, transfers from family and friends, and other implicit insurance arrangements. It is certainly possible that there were other sources of income that were missed by the PSID survey, but it is nevertheless almost surely the case that the people identified in this group experienced an extreme drop in their incomes. Carroll (1992) shows that these income shocks were typically transitory, in that income had generally recovered to its previous level within a couple of years after the zero-income event.
} 
The solid line in Figure 3 shows the results from solving the model under our alternative parameterization. Rather than growing steadily until retirement (as under the baseline HSZ parameter values), the net wealth ratio now appears to hover around a constant "target" level until around age 50. Only after age 50 does the wealth ratio begin rising sharply in anticipation of retirement. The characteristics of the kind of "target" or "buffer-stock" saving behavior that consumers in this model engage in before age 50 have been explored extensively in Carroll (1992, 1993). Those papers demonstrates that the logic behind the target-saving behavior is that precautionary motives prevent wealth from getting too low, while "impatience" (in the sense described above) prevents assets from growing too large.

The dashed line in Figure 3 shows the results when we again undertake the experiment of changing the value of the variance of permanent shocks from its baseline value of 0.1 to 0.05 , as we did above in Figure 1 for the HSZ version of the model. In contrast with the HSZ results, the effect on the lifetime profile of the net wealth ratio is rather modest: the target wealth ratio declines by roughly the same amount at every age before 50. This impression is confirmed in Figure 4 , which calculates the lifetime profile of the coefficient on $\sigma_{\eta}{ }^{2}$. This figure is sharply different from the analogous Figure 2 calculated using the HSZ parameter values, in two respects. First, rather than rising sharply in early life and then declining sharply later, under our parameter values the predicted coefficient is roughly constant from about age 25 to slightly before age 50 . More importantly, however, the mean value of the coefficient over these ages is only about 20 , far less than the values of over 100 that emerged under the HSZ parameter values. Although 20 is still above our average empirical estimate of about 10 , it is much closer than any of the predictions under HSZ parameter values. Note that, because the parameter values are taken from 
Carroll $(1992,1993)$, there has been no direct calibration of the theoretical model to match the empirical result.

Further analysis will be easier if we turn our attention just to the consumers in this "target saving" or "buffer-stock saving" phase of life, from roughly ages 25-50. Following Carroll (1992), we identify the "target" level of wealth w" as the level such that, if the consumer holds $w^{*}$ in period $t$, then expected wealth in period $t+1$ is also $w^{*}$. For any given set of parameter values, we can solve for the target level of wealth that prevails during the "buffer-stock" saving portion of the life cycle when income is growing at a baseline value of 3 percent a year. Our procedure for calculating the coefficient on uncertainty can then be formalized as follows. Write the $\log$ of target wealth as a function of all the parameters of the model, $\log \left(\mathrm{w}^{*}\right)=$ $f\left(\sigma_{\eta}{ }^{2}, \sigma_{\varepsilon}{ }^{2}, \rho, \pi, g, \delta\right)$ or, for notational simplicity, $\log \left(w^{*}\right)=f\left(\sigma_{\eta}{ }^{2}, \theta, \delta\right)$ where $\theta$ is the vector of other parameter values, $\theta=\left\{\sigma_{\varepsilon}^{2}, \rho, \pi, g\right\}$. The coefficient of interest is the derivative of $\log$ wealth with respect to $\sigma_{\eta}^{2}$ around the baseline parameter values. Denoting the vector of baseline parameter values as $\bar{\theta}$ and the baseline value of $\sigma_{\eta}{ }^{2}$ as $\bar{\sigma}_{\eta}{ }^{2}$, for a small perturbation e around the baseline value of $\sigma_{\eta}^{2}$ we have:

$$
\left.\frac{\partial f\left(\sigma_{n}{ }^{2}, \theta, \delta\right)}{\partial \sigma_{n}{ }^{2}}\right|_{\theta=\bar{\theta}, \sigma_{n}{ }^{2}=\bar{\sigma}_{n}{ }^{2}, \delta=\bar{\delta}} \approx \frac{f\left(\bar{\sigma}_{n}{ }^{2}+e, \bar{\theta}, \bar{\delta}\right)-f\left(\bar{\sigma}_{n}{ }^{2}-e, \bar{\theta}, \bar{\delta}\right)}{2 e}
$$

This equation highlights the fact that, if $\mathrm{f}$ is nonlinear, the coefficient on the variance of permanent shocks will in general depend upon our assumptions about the baseline values for all of the parameters of the model. With the exception of the time preference rate, $\delta$, our baseline parametric choices are consistent with empirical estimates in the literature. In our view, however, 
there is little credible evidence on the appropriate value of $\delta^{31}$ One way to interpret our empirical results, therefore, is by asking what values of $\delta$ would be consistent with our empirical estimates. That is, taking as fixed the values of the other parameters, for a given estimate of the coefficient on $\sigma_{\eta}^{2}$ (call it $\mathrm{C}$ ), we can search for the $\delta$ such that:

$$
\left.\frac{\partial f\left(\sigma_{n}{ }^{2}, \theta, \delta\right)}{\partial \sigma_{n}{ }^{2}}\right|_{\theta=\bar{\theta}, \sigma_{n}{ }^{2}=\bar{\sigma}_{n}{ }^{2}}=C
$$

This idea is easier to follow by considering Figure 5, which shows the results of performing the calculation on the right hand side of equation (16) for a wide range of possible values for $\bar{\delta}$, under the baseline values specified above for the other parameters. This should approximately correspond to the model's prediction, for each value of $\bar{\delta}$, of the coefficient in a regression of log wealth on the variance of permanent income shocks.

For the specification in Table 3 with NHNBW as the dependent variable, the estimate of the coefficient on $\sigma_{\eta}{ }^{2}$ was 9.4, with a standard error of 3.0. As shown in the figure, the value of $\delta$ that corresponds to an $\sigma_{\eta}{ }^{2}$ coefficient of 9.4 is 10.6 percent per year; thus, our empirical estimate of the coefficient on NHNBW in Table 3 implies a point estimate of the rate of time preference of 10.6 percent per year. However, the two-standard-deviation bands around the coefficient estimate on $\sigma_{\eta}{ }^{2}$ encompass values of $\delta$ ranging from 4.7 percent to 47.8 percent.

Because there is certainly room for disagreement with our choices for baseline values of other parameters, it is important to determine whether our conclusions about the location of $\delta$ would change dramatically under alternative but still plausible parametric assumptions. Table

\footnotetext{
${ }^{31}$ One of the few papers to attempt an empirical estimate of $\delta$ is Lawrance (1991). The results of that study are critiqued in Carroll (1995).
} 
5 presents some evidence in this regard: it shows the point estimate and the two-standard-error range for $\delta$ if we try two alternative values for each of the important parameters in the model. Unfortunately, the conclusion about the location of $\delta$ is somewhat sensitive to the choices of other parameter values, with the point estimates ranging from about 5 percent to about 14 percent per year.

Of course, if we choose an entirely different constellation of parameter values, rather than just allowing them to diverge one-by-one from our baseline assumptions, the results can change more. This is illustrated by the last row in the table, which reflects the results when all parameter values except the time preference rate are set to HSZ values and income growth is assumed to proceed at two percent a year (which corresponds to the most rapid rate of income growth estimated by HSZ for any period of life). The point estimate of the time preference rate is 38 percent, and the two-standard-error band ranges from 21 percent to 79 percent. (If income growth had been assumed to be lower, the estimates of $\delta$ would have been even higher.) The interpretation of this is that the model solved under HSZ values for all parameters other than $\delta$ is consistent with our empirical results only if the time preference rate is at least 21 percent annually, rather than the 3 percent that $\mathrm{HSZ}$ assumed. Such a high time preference rate strikes us as implausible.

The foregoing analysis has focused on the coefficient on the variance of permanent noncapital income in our empirical regressions and has ignored the other uncertainty coefficient we estimated, on the variance of transitory income. A parallel exercise can be performed using the estimates of the coefficient on transitory income; the results do not differ greatly from those obtained by examining the effect of permanent variance. For our purposes it is sufficient to note 
that the two-standard-error bands for the estimates of $\delta$ implied by a parallel analysis of transitory uncertainty generally contained the point estimate of $\delta$ from the analysis of the coefficient on permanent uncertainty. ${ }^{32}$

The intuitive reason that consumers engaged in buffer-stock saving behavior do not react strongly to uncertainty in permanent income is that, speaking in the loose sense of Friedman (1957), these consumers behave as though they have a short "horizon." More formally, Carroll (1995) shows that, under the base parameters used in this paper (including a time preference rate of 4 percent annually), buffer-stock consumers behave as though they discount future income at an average rate of around 22 percent, ${ }^{33}$ implying a Friedman-style "horizon" of less than 5 years. The reason impatient buffer-stock consumers discount future income so heavily is precautionary: they are unwilling to spend today a dollar that in expectation will, but just possibly might not, arrive tomorrow. By contrast, for consumers who are as patient as HSZ assume, future income is discounted very little (at close to the real interest rate), and so a risk to the entire stream of future income (i.e. the risk of a permanent shocks) is much more worrisome than for shorthorizon consumers.

\section{Conclusion}

\footnotetext{
${ }^{32}$ Another reason we prefer to concentrate on the results for permanent income uncertainty is that, as discussed above, the level of transitory income uncertainty may be inflated by measurement error. This is less likely to be a problem with our estimates of permanent uncertainty.

${ }^{33}$ The exact experiment was as follows. The target wealth-to-income ratio was calculated for buffer-stock consumers under the baseline parametric assumptions, and under an alternative assumption about the growth rate of income in which income was expected to grow $1 \%$ faster in every future year. The increase in the expected growth rate of income increased consumption by a fixed amount, $\Delta \mathrm{C}$, for standard "human wealth" reasons. The "effective" interest rate was then calculated as the interest rate at which, in a certainty-equivalent world, the $1 \%$ increase in the growth rate of income would have resulted in the change in consumption predicted by the buffer-stock model. So an exact statement of the result would be that a certainty-equivalent consumer would have to be facing an interest rate of $22 \%$ in order to be as unresponsive to a change in expected growth as the buffer-stock consumer.
} 
This paper presents some of the first empirical evidence that consumers who face greater income uncertainty hold more wealth. The empirical part of the paper decomposes income uncertainty into a variance of transitory shocks and a variance of permanent shocks. Both transitory and permanent uncertainty are statistically significant in predicting the levels of household wealth for three different definitions of wealth.

We further show that our empirical results are strongly inconsistent with a version of the life cycle model like that advocated by Hubbard, Skinner, and Zeldes (1994) in which the time preference rate is low enough for retirement saving to be important at early ages. A model with such patient consumers predicts a far larger response than we find of wealth holdings to the degree of risk in permanent income: the regression coefficient on the variance of permanent income predicted by the model with patient consumers is roughly an order of magnitude larger than the coefficient we estimated. These extreme results are not due to unusual assumptions about consumers' prudence (the intensity of their precautionary saving motive) or about the magnitude of income shocks (which, if anything, are conservatively chosen in the simulations). Rather, they arise because rational consumers realize that permanent shocks to income will last the rest of their lives; if consumers are patient and even modestly prudent, the present discounted utility effect from a possible negative shock to permanent income is very large and therefore justifies a large saving response.

The inability of the life cycle model under the HSZ parameterization to explain our empirical results does not imply that the intertemporal optimization framework should be abandoned. Instead, we show that the empirical results are consistent with a "buffer stock" saving configuration of the model that emerges when consumers are more impatient than in the 
HSZ parameterization and face a steeper income growth path. In the buffer stock version of the model, rather than saving for retirement from very early in life, consumers spend most of their working lifetimes trying to maintain a modest "target" wealth-to-income ratio; they begin saving for retirement only around age 50 , or when retirement is just 15 years away.

Of course, the buffer stock framework cannot explain all consumer saving behavior. For instance, it is difficult to explain why impatient consumers like ours would choose to participate in a pension plan when young (although Samwick (1994) shows that if pension participation is treated as exogenous, the common empirical finding of low substitutability between retirement and personal assets is consistent with the buffer-stock model). Explanations of high saving rates by some young households, the saving behavior related to housing, and the decision of households to build equity in personal businesses may require a more elaborate model. Thus, the chief contribution of buffer-stock model is not to be found in accounting for the bulk of the aggregate capital stock. Instead, the model is most plausible as an explanation of working consumers' direct holdings of assets which could be liquidated in the case of unlucky income draws and of their reactions to changes in the uncertainty in their economic environment. If even this more modest claim is true, however, a version of the life cycle model where consumers engage in buffer-stock saving over most of the lifetime may be more appropriate than a traditional or HSZ version of the model for understanding the behavior of consumption, income, and wealth at high and medium-term (business cycle) frequencies. 


\section{Appendix}

\section{1) Sample Restrictions Imposed}

As described in Section III, we make several sample restrictions in order to prevent the measures of income uncertainty from being affected by income changes that may not correspond to uncertainty in the sense required by the model. In addition to those households which experienced a major change in composition, we exclude all households in which the head was younger than 25 or older than 50 at any time during the sample period. The rationale is that younger individuals are not likely to be in stable households and the precautionary saving decisions of older households are likely to be confounded by retirement issues (as suggested by the simulation results). We also exclude those households whose income in any year was less than 20 percent of its average over the period. This exclusion is necessary in order to calculate our measures of uncertainty; if these households are included our results tend to be almost entirely dominated by a few observations. We also restrict the sample by excluding those households who were included in the PSID's poverty sample. All of these restrictions reduce the amount of income variability in the data.

Finally, we use income data only from the years 1981-1987, with the intent that choosing a period centered around 1984 will give us the best possible estimates of the degree of income uncertainty near that year. Results were similar when the sample was extended to include they years 1976-1987. Although it would seem that more years of data would yield superior estimates, the other sample restrictions we impose--most notably on the age of the household head--sharply reduce the number of households we can study when the sample period is extended. The resulting point estimates are typically close, but the standard errors are larger due 
to the smaller number of observations in the sample.

2) Estimating Permanent and Transitory Variances in the Sample

\section{THE PROJECTION METHODOLOGY}

As described in the text, the variance of an income difference of length $d$ is given by (Equation (5) from Section III):

$$
\operatorname{Var}\left(r_{d}\right)=d \cdot \sigma_{\eta}^{2}+2 \cdot \sigma_{\epsilon}^{2}
$$

where $\sigma_{\eta}{ }^{2}$ and $\sigma_{\varepsilon}^{2}$ are the variances of the permanent and transitory shocks to income, respectively. We estimate $\operatorname{Var}\left(\mathrm{r}_{\mathrm{d}}\right)$ for each household by

$$
v_{d}=r_{d}^{2}=\operatorname{Var}\left(r_{d}\right)+\mu_{d}
$$

where $\mu_{\mathrm{d}}$ is a mean-zero disturbance. Using the previous equation to substitute for $\operatorname{Var}\left(\mathrm{r}_{\mathrm{d}}\right)$ yields the following regression equation:

$$
v_{d}=d \cdot \sigma_{\eta}^{2}+2 \cdot \sigma_{\epsilon}^{2}+\mu_{d}
$$

where observations are distinguished by the length of the difference d. Our method simply does OLS household by household of $\mathbf{v}=\left\{\mathrm{v}_{\mathrm{d}}(1), \ldots, \mathrm{v}_{\mathrm{d}}(\mathrm{n})\right\}^{\prime}$ on $[\mathbf{d} 2]$, where $\mathbf{d}=\{\mathrm{d}(1), \ldots, \mathrm{d}(\mathrm{n})\}^{\prime}, \mathbf{2}=$ $\{2, \ldots, 2\}^{\prime}$, and $d(t)$ is the $t^{t h}$ household difference. As discussed below, we use $n=9$ for each household. The coefficients obtained for this regression give household estimates of $\sigma_{\eta}{ }^{2}$ and $\sigma_{\varepsilon}^{2}$, which we have denoted $s_{\eta}{ }^{2}$ and $s_{\varepsilon}{ }^{2}$ in the text.

We have assumed that $\mu_{d}$ and $\mu_{d^{\prime}}$ are i.i.d. for each household, making OLS the efficient way to conduct the estimation. There does not appear to be any reason to believe that the noise in observing $r_{d}$ 's should vary with $d$ for a given observation, as the data is collected each year and $r_{d}$ represents a difference in annual incomes. For the purposes of this regression, we could 
also assume without loss of generality that the $\mu$ 's are i.i.d. across households. The reason is that the regressors for each household are identical, so that a Seemingly Unrelated Regression model would reduce to OLS household by household.

\section{ROBUSTNESS TO MA(q) SERIAL CORRELATION}

We also assert in the text that the methodology we have adopted can be made robust to serial correlation in the transitory shock of the form MA(q). This can be seen in Equation (4) from Section III:

$$
r_{d}=\left\{\eta_{t+1}+\eta_{t+2}+\ldots+\eta_{t+d}\right\}+\epsilon_{t+d}-\epsilon_{t}
$$

by noting that $\operatorname{Var}\left(\varepsilon_{\mathrm{t+d}}-\varepsilon_{\mathrm{q}}\right)=2 * \sigma_{\varepsilon}^{2}-2 * \operatorname{Cov}\left(\varepsilon_{\mathrm{t}+\mathrm{d}}, \varepsilon_{\mathrm{t}}\right)$. This will yield an unbiased estimate of $\sigma_{\varepsilon}^{2}$ whenever $\operatorname{Cov}\left(\varepsilon_{t+d}, \varepsilon_{t}\right)=0$. Thus, as long as we restrict our choices of $\mathrm{d}$ to those greater than $\mathrm{q}$, the procedure will yield the unbiased estimate. Results from MaCurdy (1982) and Abowd and Card (1989) suggest that there is no evidence of serial correlation beyond order 2 for labor income of the household head.

We choose all possible pairs of income values in which the years are at least three apart (thus making our estimates robust to serial correlation up to MA(2)) and for which more than one pair of years is available to estimate that difference. This leaves us with 9 differences for the period 1981-1987:

Length (d)

5

4
Years used

1981-1986, 1982-1987

1981-1985, 1982-1986, 1983-1987

1981-1984, 1982-1985, 1983-1986, 1984-1987 


\section{3) The Impact of Measurement Error in Income on Regression Coefficients}

In the text we demonstrated that measurement error in income would not affect the estimated variance of permanent income but would increase the estimated variance of transitory income. We argued that the most common form of measurement error would result in our estimating $s_{i \varepsilon}^{2}=\sigma_{i \varepsilon}^{2}+\sigma_{u}^{2}$ with the same $\sigma_{u}^{2}$ for all households. In a regression of the form (see equation 13):

$$
\log (W)=\alpha_{0}+\alpha_{1} s_{\eta}^{2}+\alpha_{2} s_{\epsilon}^{2}+\alpha_{3} \log (P)+X \beta+\varepsilon
$$

the $\sigma_{u}^{2}$ will simply be treated as part of the constant term. In this case the estimate of coefficient $\alpha_{2}$ should be unbiased; only $\alpha_{0}$ will be biased, and we draw no inferences from the estimated value of $\alpha_{0}$.

Consider a second, more sophisticated kind of measurement error. Suppose $\sigma_{u}^{2}$ is correlated with $\sigma_{\mathrm{i \varepsilon}}{ }^{2}$; indeed, suppose $\sigma_{\mathrm{iu}}{ }^{2}=\Gamma * \sigma_{\mathrm{i} \varepsilon}{ }^{2}$, where $\Gamma>1$ (that is, measurement error is worse for those who have higher transitory variance anyway--a plausible assumption). Then $s_{i \varepsilon}^{2}=(1+\Gamma) \sigma_{i \varepsilon}^{2}$. But the effect of this would be to bias our estimate of $\alpha_{2}$, the coefficient on transitory income, down by increasing the standard deviation of the variable that coefficient is multiplying. Since the primary focus of our attention is on the coefficients on permanent uncertainty, this point does not undermine the main results of the paper.

\section{4) Effect of Larger Groups on Negative Correlation in Uncertainty Estimates}

In Section III we assert that the negative correlation in estimates of transitory and permanent variances by group would approach zero if the group size approached infinity. In our simplified example using only two differences to estimate $s_{\eta}{ }^{2}$ and $s_{\varepsilon}{ }^{2}$, we had the following 
equations:

$$
\begin{aligned}
& s_{i \eta}^{2}=\sigma_{i \eta}{ }^{2}+z_{i} \\
& s_{i \epsilon}^{2}=\sigma_{i \epsilon}^{2}-\frac{(d-1) z_{i}}{2}
\end{aligned}
$$

where the subscript $i$ refers to household $i$ and the $z_{i}$ are mean-zero and independent across households and $\operatorname{Var}\left(\mathrm{z}_{\mathrm{i}}\right)=\sigma_{\mathrm{iz}}{ }^{2}<\infty$. Divide the population into $\mathrm{K}$ groups of $\mathrm{N}$ observations each. The covariance across groups is given by:

$$
K^{-1} \sum_{k=1}^{K}\left[N^{-1} \sum_{i=1}^{N}\left(s_{i \eta}^{2}-\sigma_{i \eta}^{2}\right)\right]\left[N^{-1} \sum_{i=1}^{N}\left(s_{i \epsilon}^{2}-\sigma_{i \epsilon}^{2}\right)\right]
$$

which is equivalent to

$$
K^{-1} \sum_{k=1}^{K}\left[N^{-1} \sum_{i=1}^{N} z_{i}\right]\left[N^{-1} \sum_{i=1}^{N}-\frac{(d-1)}{2} z_{i}\right]
$$

and can be simplified to

$$
K^{-1} \sum_{k=1}^{K}\left[N^{-1} \sum_{i=1}^{N}-\frac{(d-1)}{2} \frac{z_{i}^{2}}{N}+N^{-2} \sum_{i=1}^{N} \sum_{i \neq j}-\frac{(d-1)}{2} z_{i} z_{j}\right]
$$

The first summation within the brackets converges to zero as $N$ gets large because $E\left(z_{i}^{2}\right)$ $=\sigma_{\mathrm{iz}}{ }^{2}<\infty$. The second summation converges to zero as $\mathrm{N}$ gets large because the $\mathrm{z}_{\mathrm{i}}$ 's are independently distributed. This proves the proposition. More generally, the result will obtain whenever $\left\{\mathbf{z}_{\mathrm{i}}\right\}$ satisfies a Law of Large Numbers. 


\section{References}

Abowd, John M. and David Card (1989). "On the Covariance Structure of Earnings and Hours Changes," Econometrica, Vol. 57, 411-445.

Avery, Robert B., Gregory E. Elliehausen, and Glenn B. Canner (1984a). "Survey of Consumer Finances, 1983," Federal Reserve Bulletin, Vol. 70, 679-692.

Avery, Robert B., Gregory E. Elliehausen, and Glenn B. Canner (1984b). "Survey of Consumer Finances, 1983: A Second Report," Federal Reserve Bulletin, Vol. 70, 857-868.

Bound, John, David A. Jaeger, and Regina Baker (1993). "The Cure Can Be Worse Than the Disease: A Cautionary Tale Regarding Instrumental Variables," NBER Technical Working Paper No. 137.

Caballero, Ricardo J. (1990). "Consumption Puzzles and Precautionary Savings," Journal of Monetary Economics, Vol. 25, 113-136.

Caballero, Ricardo J. (1991). "Earnings Uncertainty and Aggregate Wealth Accumulation," American Economic Review, Vol. 81, 859-871.

Carroll, Christopher D. (1992). "The Buffer Stock Theory of Saving: Some Macroeconomic Evidence," Brookings Papers on Economic Activity, Vol 2, 61-135.

Carroll, Christopher D. (1995). "Buffer Stock Saving and the Permanent Income Hypothesis," Manuscript, Federal Reserve Board.

Carroll, Christopher D. (1994). "How Does Future Income Affect Current Consumption?" Quarterly Journal of Economics, Vol. 109, pp. 111-147.

Carroll, Christopher D. and Andrew A. Samwick (1995). "How Important Is Precautionary Saving?" Manuscript, Federal Reserve Board.

Carroll, Christopher D. and David N. Weil (1994). "Saving and Growth: A Reinterpretation," Carnegie-Rochester Conference Series on Public Policy, Vol. 40, pp. 133-192.

Curtin, Richard T., F. Thomas Juster and James N. Morgan (1989). "Survey Estimates of Wealth: An Assessment of Quality," in Lipsey and Tice (eds.) The Measurement of Saving, Investment, and Wealth. Chicago: University of Chicago Press, 473-552.

Dardanoni, Valentino (1991). "Precautionary savings under income uncertainty: a cross-sectional analysis," Applied Economics, Vol. 23, 153-160.

Deaton, Angus (1991). "Saving and Liquidity Constraints," Econometrica, Vol. 59, 1121-1142. 
Dynan, Karen E. (1993). "How Prudent Are Consumers?" Journal of Political Economy, Vol. 101, No. 6, 1104-1113.

Eugeni, Francesca (1993). "Consumer Debt and Home Equity Borrowing," Economic Perspectives, Federal Reserve Bank of Chicago, (March/April), 2-14.

Friedman, Milton (1957). A Theory of the Consumption Function, Princeton: Princeton University Press.

Guiso, Luigi, Tullio Jappelli and Daniele Terlizzese (1992). "Earnings Uncertainty and Precautionary Saving," Journal of Monetary Economics, Vol. 30, 307-332.

Hall, Alastair R., Glenn D. Rudebusch, and David W. Wilcox (1994). "Judging Instrument Relevance in Instrumental Variables Estimation," Federal Reserve Board, Finance and Economics Discussion Paper No. 94-3.

Hall, Robert E. and Frederic S. Mishkin (1982). "The Sensitivity of Consumption to Transitory Income: Estimates from Panel Data on Households," Econometrica, Vol. 50, 461-481.

Hansen, Lars P. (1982). "Large Sample Properties of Generalized Method of Moments Estimators," Econometrica, Vol. 50, 1029-1054.

Hubbard, R. Glenn, Jonathan S. Skinner, and Stephen P. Zeldes (1994). "The Importance of Precautionary Motives for Explaining Individual and Aggregate Saving," in Allan H. Meltzer and Charles I. Plosser (eds.) Carnegie-Rochester Conference Series on Public Policy, Vol. 40, 59-126.

Hubbard, R. Glenn, Jonathan S. Skinner, and Stephen P. Zeldes (1995). "Precautionary Saving and Social Insurance," Journal of Political Economy, Vol. 103, No. 2, 360-399.

Kimball, Miles S. (1990a). "Precautionary Saving in the Small and in the Large," Econometrica, Vol. 58, 53-73.

Kimball, Miles S. (1990b). "Precautionary Saving and the Marginal Propensity to Consume," NBER Working Paper, No. 3403.

Kimball, Miles S. (1991). "Precautionary Motives for Holding Assets," NBER Working Paper, No. 3586.

Kimball, Miles S. and N. Gregory Mankiw (1989). "Precautionary Saving and the Timing of Taxes," Journal of Political Economy, Vol. 97, No. 4, 863-879.

Lawrance, Emily C. (1991). "Poverty and the Rate of Time Preference: Evidence from Panel Data," Journal of Political Economy, Vol. 99, 54-77. 
MaCurdy, Thomas E. (1982). "The Use of Time Series Processes to Model the Error Structure of Earnings in Longitudinal Data Analysis," Journal of Econometrics, Vol. 18, 83-114.

Nelson, Charles R. and Richard Startz (1990a). "The Distribution of the Instrumental Variables Estimator and Its t-Ratio When the Instrument Is a Poor One," Journal of Business, Vol. 63, 125140.

Nelson, Charles R. and Richard Startz (1990b). "Some Further Results on the Exact Small Sample Properties of the Instrumental Variable Estimator," Econometrica, Vol. 58, 967-976.

Quah, Danny (1990). "Permanent and Transitory Movements in Labor Income: An Explanation for 'Excess Smoothness' in Consumption," Journal of Political Economy, Vol. 98, 449-475.

Samwick, Andrew A. (1994). "The Limited Offset Between Pension Wealth and Other Private Wealth: Implications of Buffer-Stock Saving," mimeo, Dartmouth College.

Skinner, Jonathan (1988). "Risky Income, Life Cycle Consumption, and Precautionary Savings," Journal of Monetary Economics, Vol. 22, 237-255.

Staiger, Douglas, and James H. Stock (1994). "Instrumental Variables Regression with Weak Instruments," NBER Technical Working Paper No. 151.

Summers, Lawrence H. (1982). "Tax Policy, the Rate of Return, and Savings." NBER Working Paper, No. 995.

Zeldes, Stephen P. (1989). "Optimal Consumption with Stochastic Income: Deviations from Certainty Equivalence," Quarterly Journal of Economics, Vol. 104, 275-98. 


\begin{tabular}{|c|c|c|c|c|}
\hline \multicolumn{5}{|c|}{ Table 1} \\
\hline \multicolumn{5}{|c|}{$\begin{array}{l}\text { Variance of Permanent and Transitory Income Shocks } \\
\text { by Occupation, Education, and Industry Groups }\end{array}$} \\
\hline Group & $\begin{array}{l}\text { Average Annual } \\
\text { Income Variance } \\
\text { (Standard Error) }\end{array}$ & $\begin{array}{c}\text { Estimated Variance of } \\
\text { Permanent Component } \\
\text { (Standard Error) }\end{array}$ & $\begin{array}{c}\text { Estimated Variance of } \\
\text { Transitory Component } \\
\text { (Standard Error) }\end{array}$ & $\begin{array}{c}\text { Percent of } \\
\text { Sample } \\
(\mathrm{N}=1325)\end{array}$ \\
\hline Full Sample & $\begin{array}{c}0.0355 \\
(0.0018)\end{array}$ & $\begin{array}{c}0.0217 \\
(0.0029) \\
\end{array}$ & $\begin{array}{c}0.0440 \\
(0.0055) \\
\end{array}$ & 100.00 \\
\hline \multicolumn{5}{|l|}{ Occupation } \\
\hline $\begin{array}{l}\text { Professional and } \\
\text { Technical Workers }\end{array}$ & $\begin{array}{c}0.0292 \\
(0.0039)\end{array}$ & $\begin{array}{c}0.0172 \\
(0.0062)\end{array}$ & $\begin{array}{c}0.0331 \\
(0.0116)\end{array}$ & 22.3 \\
\hline $\begin{array}{l}\text { Managers (not } \\
\text { self-employed) }\end{array}$ & $\begin{array}{c}0.0321 \\
(0.0050)\end{array}$ & $\begin{array}{c}0.0180 \\
(0.0081)\end{array}$ & $\begin{array}{c}0.0357 \\
(0.0151)\end{array}$ & 13.2 \\
\hline $\begin{array}{l}\text { Self-employed } \\
\text { Managers }\end{array}$ & $\begin{array}{c}0.0453 \\
(0.0089)\end{array}$ & $\begin{array}{c}0.0165 \\
(0.0143)\end{array}$ & $\begin{array}{c}0.0926 \\
(0.0267)\end{array}$ & 4.2 \\
\hline $\begin{array}{l}\text { Clerical and } \\
\text { Sales Workers }\end{array}$ & $\begin{array}{c}0.0388 \\
(0.0048)\end{array}$ & $\begin{array}{c}0.0235 \\
(0.0078)\end{array}$ & $\begin{array}{c}0.0361 \\
(0.0145)\end{array}$ & 14.3 \\
\hline Craftsmen & $\begin{array}{c}0.0285 \\
(0.0041)\end{array}$ & $\begin{array}{c}0.0175 \\
(0.0066)\end{array}$ & $\begin{array}{c}0.0432 \\
(0.0123)\end{array}$ & 20.0 \\
\hline $\begin{array}{l}\text { Operatives and } \\
\text { Laborers }\end{array}$ & $\begin{array}{c}0.0403 \\
(0.0044)\end{array}$ & $\begin{array}{c}0.0299 \\
(0.0071)\end{array}$ & $\begin{array}{c}0.0458 \\
(0.0133)\end{array}$ & 17.1 \\
\hline $\begin{array}{l}\text { Farmers and Farm } \\
\text { Laborers }\end{array}$ & $\begin{array}{c}0.0660 \\
(0.0119)\end{array}$ & $\begin{array}{c}0.0450 \\
(0.0192)\end{array}$ & $\begin{array}{c}0.1016 \\
(0.0359)\end{array}$ & 2.3 \\
\hline Service Workers & $\begin{array}{c}0.0490 \\
(0.0071)\end{array}$ & $\begin{array}{c}0.0189 \\
(0.0116)\end{array}$ & $\begin{array}{c}0.0611 \\
(0.0215)\end{array}$ & 6.5 \\
\hline \multicolumn{5}{|l|}{ Education } \\
\hline $0-8$ Grades & $\begin{array}{c}0.0382 \\
(0.0085)\end{array}$ & $\begin{array}{c}0.0190 \\
(0.0137)\end{array}$ & $\begin{array}{c}0.0894 \\
(0.0256)\end{array}$ & 4.6 \\
\hline 9-12 Grades & $\begin{array}{c}0.0459 \\
(0.0056)\end{array}$ & $\begin{array}{c}0.0214 \\
(0.0090)\end{array}$ & $\begin{array}{c}0.0658 \\
(0.0168)\end{array}$ & 10.6 \\
\hline $\begin{array}{l}\text { High School } \\
\text { Diploma }\end{array}$ & $\begin{array}{c}0.0383 \\
(0.0043)\end{array}$ & $\begin{array}{c}0.0277 \\
(0.0069)\end{array}$ & $\begin{array}{c}0.0431 \\
(0.0129)\end{array}$ & 18.0 \\
\hline $\begin{array}{l}\text { Some College, } \\
\text { No Degree }\end{array}$ & $\begin{array}{c}0.0353 \\
(0.0029)\end{array}$ & $\begin{array}{c}0.0238 \\
(0.0047)\end{array}$ & $\begin{array}{c}0.0342 \\
(0.0088)\end{array}$ & 38.8 \\
\hline College Degree & $\begin{array}{c}0.0284 \\
(0.0042)\end{array}$ & $\begin{array}{c}0.0146 \\
(0.0068)\end{array}$ & $\begin{array}{c}0.0385 \\
(0.0126)\end{array}$ & 18.9 \\
\hline $\begin{array}{l}\text { Some Advanced } \\
\text { Education }\end{array}$ & $\begin{array}{c}0.0324 \\
(0.0061)\end{array}$ & $\begin{array}{c}0.0115 \\
(0.0097)\end{array}$ & $\begin{array}{c}0.0500 \\
(0.0181)\end{array}$ & 9.1 \\
\hline
\end{tabular}




\begin{tabular}{|c|c|c|c|c|}
\hline \multicolumn{5}{|c|}{ Table 1 (Continued) } \\
\hline Group & $\begin{array}{l}\text { Average Annual } \\
\text { Income Variance } \\
\text { (Standard Error) }\end{array}$ & $\begin{array}{l}\text { Estimated Variance of } \\
\text { Permanent Component } \\
\text { (Standard Error) }\end{array}$ & $\begin{array}{l}\text { Estimated Variance of } \\
\text { Transitory Component } \\
\text { (Standard Error) }\end{array}$ & $\begin{array}{c}\text { Percent of } \\
\text { Sample } \\
(\mathrm{N}=1325)\end{array}$ \\
\hline \multicolumn{5}{|l|}{ Industry } \\
\hline $\begin{array}{l}\text { Agriculture, } \\
\text { Forestry, Fishing }\end{array}$ & $\begin{array}{c}0.0596 \\
(0.0096)\end{array}$ & $\begin{array}{c}0.0401 \\
(0.0155)\end{array}$ & $\begin{array}{c}0.0794 \\
(0.0288)\end{array}$ & 3.6 \\
\hline Mining & $\begin{array}{c}0.0431 \\
(0.0172)\end{array}$ & $\begin{array}{c}0.0389 \\
(0.0277)\end{array}$ & $\begin{array}{l}-0.0018 \\
(0.0516)\end{array}$ & 1.1 \\
\hline Construction & $\begin{array}{c}0.0452 \\
(0.0072)\end{array}$ & $\begin{array}{c}0.0313 \\
(0.0116)\end{array}$ & $\begin{array}{c}0.0494 \\
(0.0215)\end{array}$ & 6.5 \\
\hline Manufacturing & $\begin{array}{c}0.0317 \\
(0.0034)\end{array}$ & $\begin{array}{c}0.0249 \\
(0.0055)\end{array}$ & $\begin{array}{c}0.0275 \\
(0.0102)\end{array}$ & 28.9 \\
\hline $\begin{array}{l}\text { Transportation, } \\
\text { Communication, \& } \\
\text { Utilities }\end{array}$ & $\begin{array}{c}0.0302 \\
(0.0056)\end{array}$ & $\begin{array}{c}0.0111 \\
(0.0090)\end{array}$ & $\begin{array}{c}0.0603 \\
(0.0167)\end{array}$ & 10.8 \\
\hline $\begin{array}{l}\text { Wholesale and } \\
\text { Retail Trade }\end{array}$ & $\begin{array}{c}0.0408 \\
(0.0048)\end{array}$ & $\begin{array}{c}0.0231 \\
(0.0078)\end{array}$ & $\begin{array}{c}0.0489 \\
(0.0145)\end{array}$ & 14.3 \\
\hline $\begin{array}{l}\text { Finance, } \\
\text { Insurance, and } \\
\text { Real Estate }\end{array}$ & $\begin{array}{c}0.0286 \\
(0.0082)\end{array}$ & $\begin{array}{c}0.0118 \\
(0.0133)\end{array}$ & $\begin{array}{c}0.0510 \\
(0.0248)\end{array}$ & 4.9 \\
\hline $\begin{array}{l}\text { Business and } \\
\text { Repair Services }\end{array}$ & $\begin{array}{c}0.0256 \\
(0.0095)\end{array}$ & $\begin{array}{c}0.0037 \\
(0.0153)\end{array}$ & $\begin{array}{c}0.0662 \\
(0.0285)\end{array}$ & 3.7 \\
\hline Personal Services & $\begin{array}{c}0.0655 \\
(0.0147)\end{array}$ & $\begin{array}{c}0.0200 \\
(0.0229)\end{array}$ & $\begin{array}{c}0.1040 \\
(0.0426)\end{array}$ & 1.7 \\
\hline $\begin{array}{l}\text { Entertainment } \\
\text { and Recreation } \\
\text { Services }\end{array}$ & $\begin{array}{c}0.0329 \\
(0.0251)\end{array}$ & $\begin{array}{c}0.0107 \\
(0.0405)\end{array}$ & $\begin{array}{c}0.0892 \\
(0.0755)\end{array}$ & 0.5 \\
\hline $\begin{array}{l}\text { Professional and } \\
\text { Related Services }\end{array}$ & $\begin{array}{c}0.0392 \\
(0.0045)\end{array}$ & $\begin{array}{c}0.0216 \\
(0.0072)\end{array}$ & $\begin{array}{c}0.0469 \\
(0.0136)\end{array}$ & 16.4 \\
\hline $\begin{array}{l}\text { Public } \\
\text { Administration }\end{array}$ & $\begin{array}{c}0.0218 \\
(0.0066) \\
\end{array}$ & $\begin{array}{c}0.0119 \\
(0.0107) \\
\end{array}$ & $\begin{array}{c}0.0218 \\
(0.0200) \\
\end{array}$ & 7.6 \\
\hline \multicolumn{5}{|c|}{$\begin{array}{l}\text { Notes: } \\
\text { 1) Group designations pertain to the head of household in the beginning year of the sample (1981). } \\
\text { 2) The first column is the variance of the unexplained component of the difference in income between the } \\
\text { beginning and end of the sample period (1981-1987), divided by the length of the sample period. }\end{array}$} \\
\hline
\end{tabular}




\begin{tabular}{|c|c|c|c|c|c|c|}
\hline \multicolumn{7}{|c|}{ Table 2} \\
\hline \multicolumn{7}{|c|}{ Descriptive Statistics of Wealth Measures in the PSID and the SCF } \\
\hline & \multicolumn{2}{|c|}{$\begin{array}{l}\text { Very Liquid } \\
\text { Assets }\end{array}$} & \multicolumn{2}{|c|}{$\begin{array}{c}\text { Non-Housing, } \\
\text { Non-Business Wealth }\end{array}$} & \multicolumn{2}{|c|}{$\begin{array}{c}\text { Total } \\
\text { Net Worth }\end{array}$} \\
\hline & PSID & $\mathrm{SCF}$ & PSID & SCF & PSID & SCF \\
\hline \multicolumn{7}{|l|}{ Level of Wealth } \\
\hline Mean & 16,790 & 24,118 & 38,951 & 36,665 & 87,086 & 107,164 \\
\hline Median & 5,000 & 4,068 & 13,000 & 13,384 & 47,000 & 49,430 \\
\hline \multicolumn{7}{|l|}{$\begin{array}{l}\text { Ratio of Wealth to } \\
\text { Permanent Income }\end{array}$} \\
\hline Mean & 0.40 & 0.57 & 0.96 & 1.02 & 2.43 & 2.92 \\
\hline Median & 0.15 & 0.14 & 0.44 & 0.46 & 1.57 & 1.60 \\
\hline \multicolumn{7}{|l|}{$\begin{array}{l}\text { Number of } \\
\text { Observations }\end{array}$} \\
\hline Positive Wealth & 881 & 1247 & 847 & 1163 & 861 & 1243 \\
\hline No Wealth Restriction & 1001 & 1306 & 941 & 1306 & 906 & 1306 \\
\hline \multicolumn{7}{|c|}{$\begin{array}{l}\text { Notes: } \\
\text { 1) All dollar amounts are in real } 1984 \text { dollars. }\end{array}$} \\
\hline \multicolumn{7}{|c|}{$\begin{array}{l}\text { 3) The data for the SCF include the high-income sample and are weighted to represent } \\
\text { the population of households in } 1983 \text {. The data for the PSID are unweighted. }\end{array}$} \\
\hline
\end{tabular}


Table 3

Instrumental Variables Regressions of Wealth on Uncertainty

Households Aged 50 and Under

\begin{tabular}{|c|c|c|c|}
\hline & Very Liquid Assets & $\begin{array}{c}\text { Non-housing, } \\
\text { Non-business Wealth }\end{array}$ & Total Net Worth \\
\hline Constant & $\begin{array}{c}-26.33 \\
(3.49)\end{array}$ & $\begin{array}{r}-14.86 \\
(2.70)\end{array}$ & $\begin{array}{r}-12.00 \\
(2.51)\end{array}$ \\
\hline Permanent Variance & $\begin{array}{l}12.09^{* *} \\
(3.93)\end{array}$ & $\begin{array}{l}9.43^{* *} \\
(3.04)\end{array}$ & $\begin{array}{l}8.64^{* *} \\
(3.05)\end{array}$ \\
\hline Transitory Variance & $\begin{array}{l}7.11^{* *} \\
(2.20)\end{array}$ & $\begin{array}{r}3.88^{*} \\
(1.90)\end{array}$ & $\begin{array}{r}3.86^{*} \\
(1.78)\end{array}$ \\
\hline Permanent Income & $\begin{array}{l}3.07 \\
(0.33)\end{array}$ & $\begin{array}{c}1.94 \\
(0.25)\end{array}$ & $\begin{array}{c}1.65 \\
(0.23)\end{array}$ \\
\hline Age & $\begin{array}{c}0.14 \\
(0.10)\end{array}$ & $\begin{array}{c}0.20 \\
(0.08)\end{array}$ & $\begin{array}{c}0.21 \\
(0.08)\end{array}$ \\
\hline $\mathrm{Age}^{2} \times 10^{-2}$ & $\begin{array}{l}-0.16 \\
(0.14)\end{array}$ & $\begin{array}{l}-0.24 \\
(0.10)\end{array}$ & $\begin{array}{l}-0.23 \\
(0.10)\end{array}$ \\
\hline Married & $\begin{array}{l}-0.50 \\
(0.25)\end{array}$ & $\begin{array}{c}0.00 \\
(0.20)\end{array}$ & $\begin{array}{c}0.47 \\
(0.20)\end{array}$ \\
\hline Race & $\begin{array}{c}0.30 \\
(0.24)\end{array}$ & $\begin{array}{c}0.29 \\
(0.19)\end{array}$ & $\begin{array}{c}0.44 \\
(0.20)\end{array}$ \\
\hline Female & $\begin{array}{c}0.01 \\
(0.17)\end{array}$ & $\begin{array}{l}0.01 \\
(0.18)\end{array}$ & $\begin{array}{l}-0.01 \\
(0.15)\end{array}$ \\
\hline Kids & $\begin{array}{l}-0.24 \\
(0.06)\end{array}$ & $\begin{array}{l}-0.11 \\
(0.05)\end{array}$ & $\begin{array}{l}-0.04 \\
(0.05)\end{array}$ \\
\hline $\begin{array}{l}\text { Overidentification } \\
\text { Test (p-value) }\end{array}$ & 0.26 & 0.50 & 0.075 \\
\hline $\begin{array}{l}\text { Number of } \\
\text { Observations }\end{array}$ & 881 & 847 & 861 \\
\hline
\end{tabular}

Notes:

1) Heteroskedasticity-robust standard errors are reported in parentheses.

2) Instrumental Variables used for the two income variances and permanent income are the occupation, education, and industry dummies listed in Table 1 and the occupation and education dummies interacted with Age and $\mathrm{Age}^{2}$.

3) Demographic variables: Married $=1$ if married, 0 otherwise; Race $=1$ if white, 0 if nonwhite; Female $=1$ if female head of household, 0 otherwise; Kids $=$ number of children under 18 in the household

4) "* and " denote statistical significance of uncertainty measures at the 1 percent and 5 percent levels, respectively. 
Table 4

Discount Rates Implied by Baseline Parameterizations of Intertemporal Consumption Problem, Mean and Two Standard Error Confidence Intervals

\begin{tabular}{|c|c|c|c|}
\hline Parameters & $\begin{array}{l}\text { Point Estimate } \\
\text { Of Discount Rate }\end{array}$ & $\begin{array}{c}\text { Two Std. Errors } \\
\text { Below }\end{array}$ & $\begin{array}{c}\text { Two Std. Errors } \\
\text { Above }\end{array}$ \\
\hline Baseline Parameters & 0.107 & 0.048 & 0.469 \\
\hline Interest Rate $=0.02$ & 0.130 & 0.069 & 0.496 \\
\hline Interest Rate $=0.04$ & 0.152 & 0.079 & 0.540 \\
\hline Growth Rate $=0.02$ & 0.140 & 0.079 & 0.513 \\
\hline Growth Rate $=0.04$ & 0.075 & 0.018 & 0.425 \\
\hline $\begin{array}{l}\text { Coefficient of Relative } \\
\text { Risk Aversion }=2\end{array}$ & 0.084 & 0.034 & 0.387 \\
\hline $\begin{array}{l}\text { Coefficient of Relative } \\
\text { Risk Aversion }=4\end{array}$ & 0.134 & 0.067 & 0.552 \\
\hline $\begin{array}{l}\text { Standard Deviation of } \\
\text { Permanent Shock }=0.05\end{array}$ & 0.046 & -0.001 & 0.331 \\
\hline $\begin{array}{l}\text { Standard Deviation of } \\
\text { Permanent Shock }=0.15\end{array}$ & 0.183 & 0.118 & 0.611 \\
\hline $\begin{array}{l}\text { Standard Deviation of } \\
\text { Transitory Shock }=0.05\end{array}$ & 0.102 & 0.046 & 0.445 \\
\hline $\begin{array}{l}\text { Standard Deviation of } \\
\text { Transitory Shock }=0.15\end{array}$ & 0.115 & 0.052 & 0.501 \\
\hline $\begin{array}{l}\text { Probability of Zero- } \\
\text { Income Event }=1 \%\end{array}$ & 0.096 & 0.040 & 0.432 \\
\hline $\begin{array}{l}\text { Probability of Zero- } \\
\text { Income Event }=0.1 \%\end{array}$ & 0.136 & 0.067 & 0.551 \\
\hline $\begin{array}{l}\text { Hubbard-Skinner-Zeldes } \\
\text { Parameters }\end{array}$ & 0.383 & 0.210 & 0.786 \\
\hline
\end{tabular}




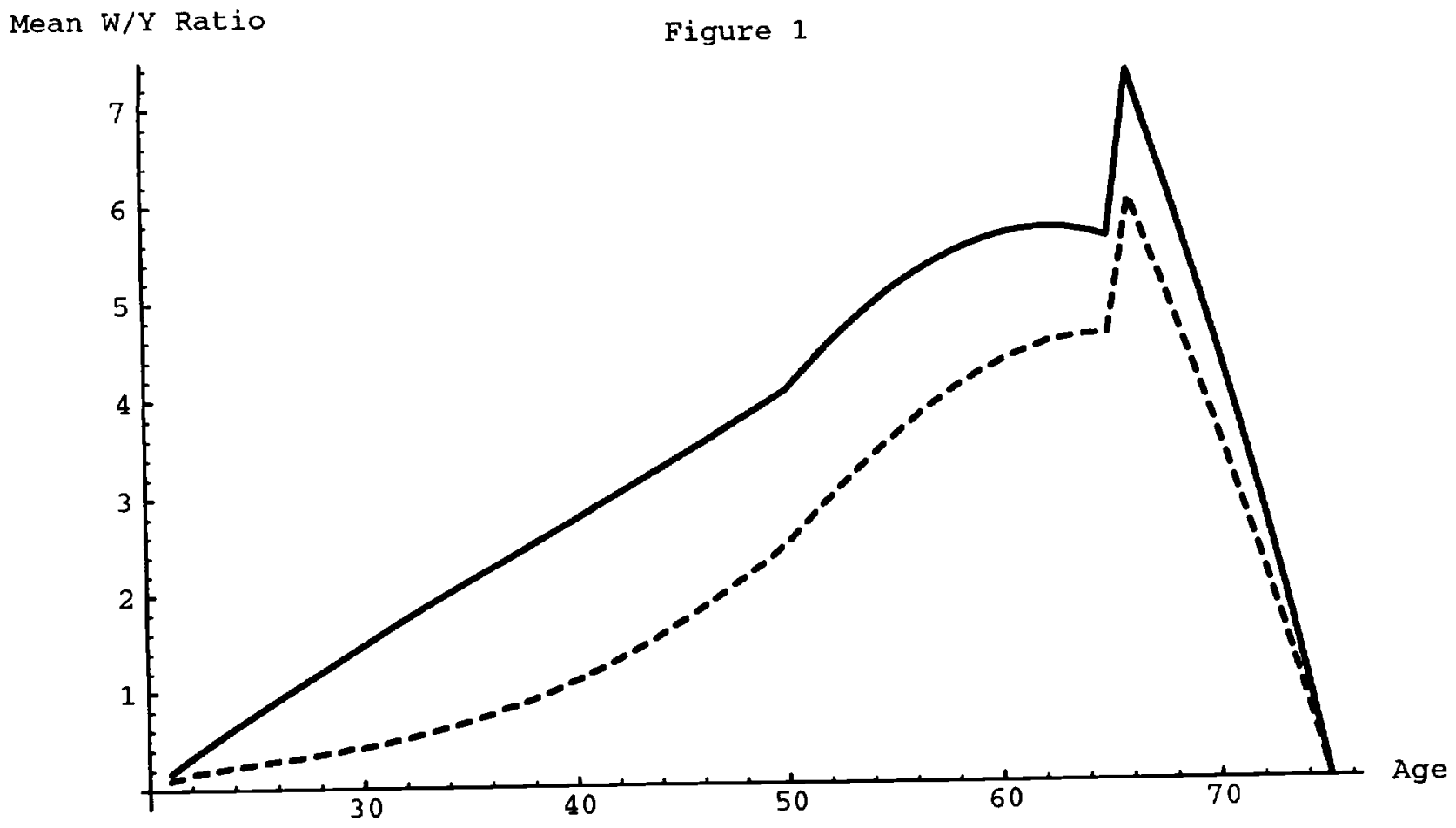




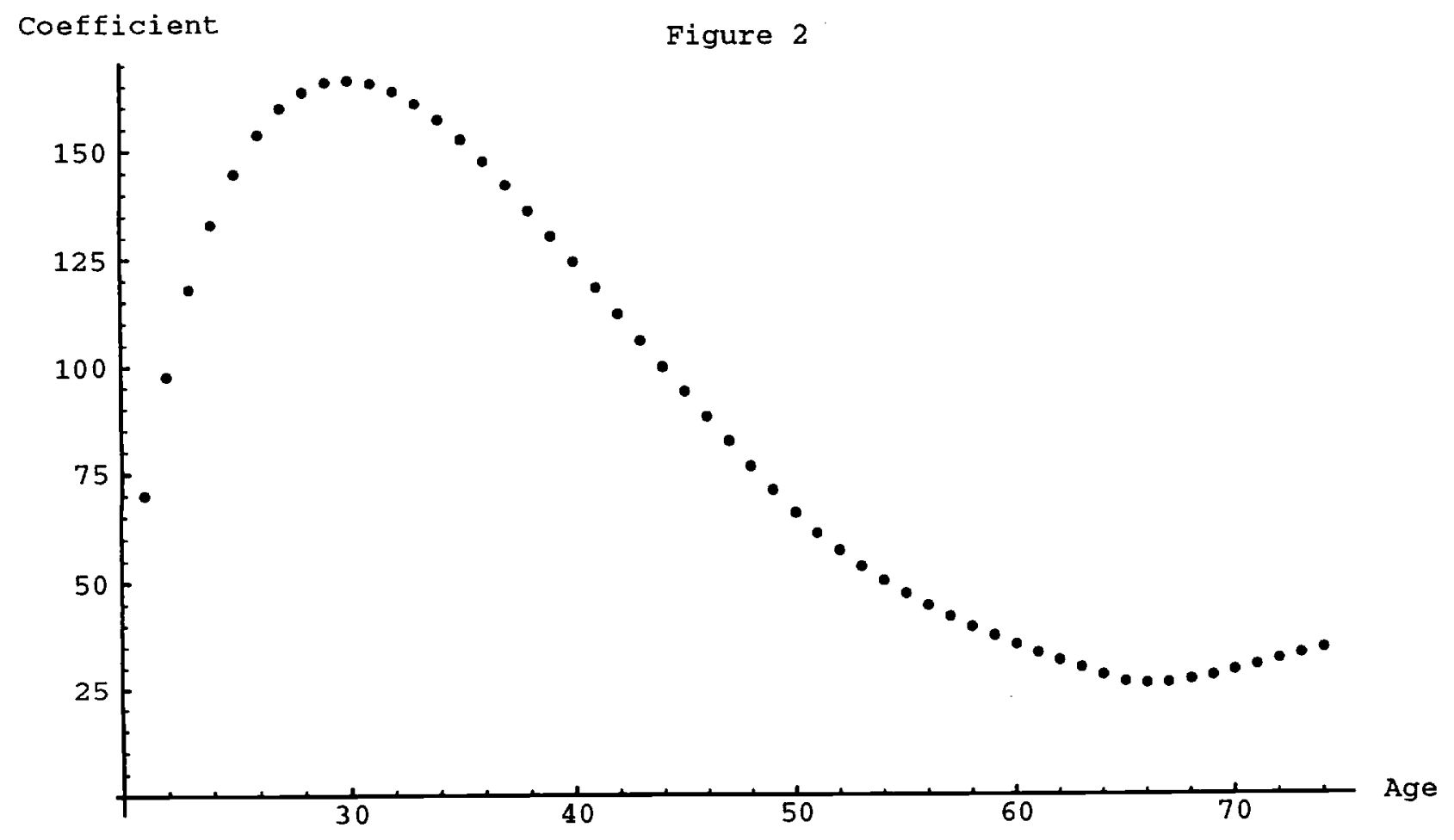


Mean W/Y Ratio

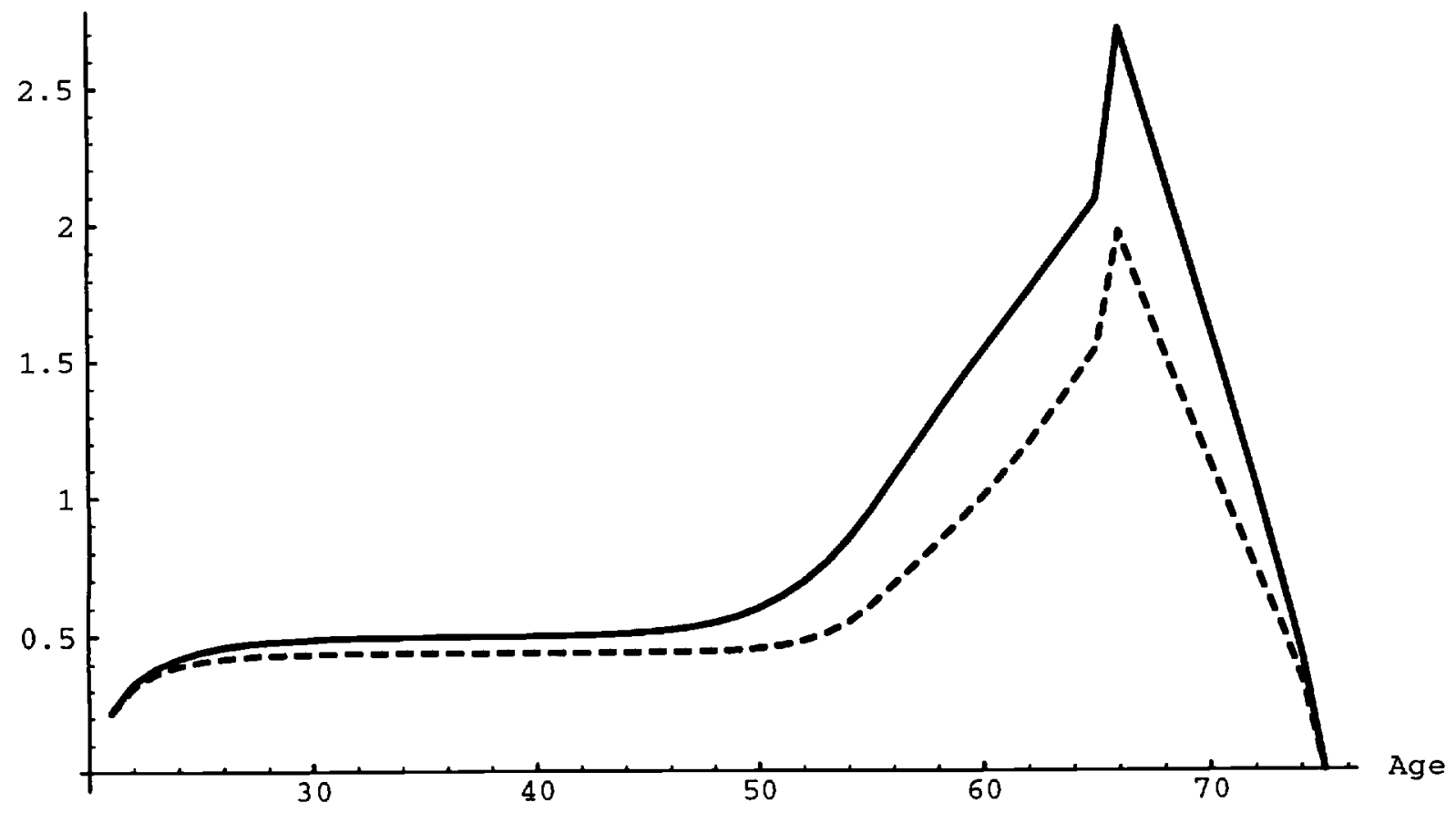

Figure 3 


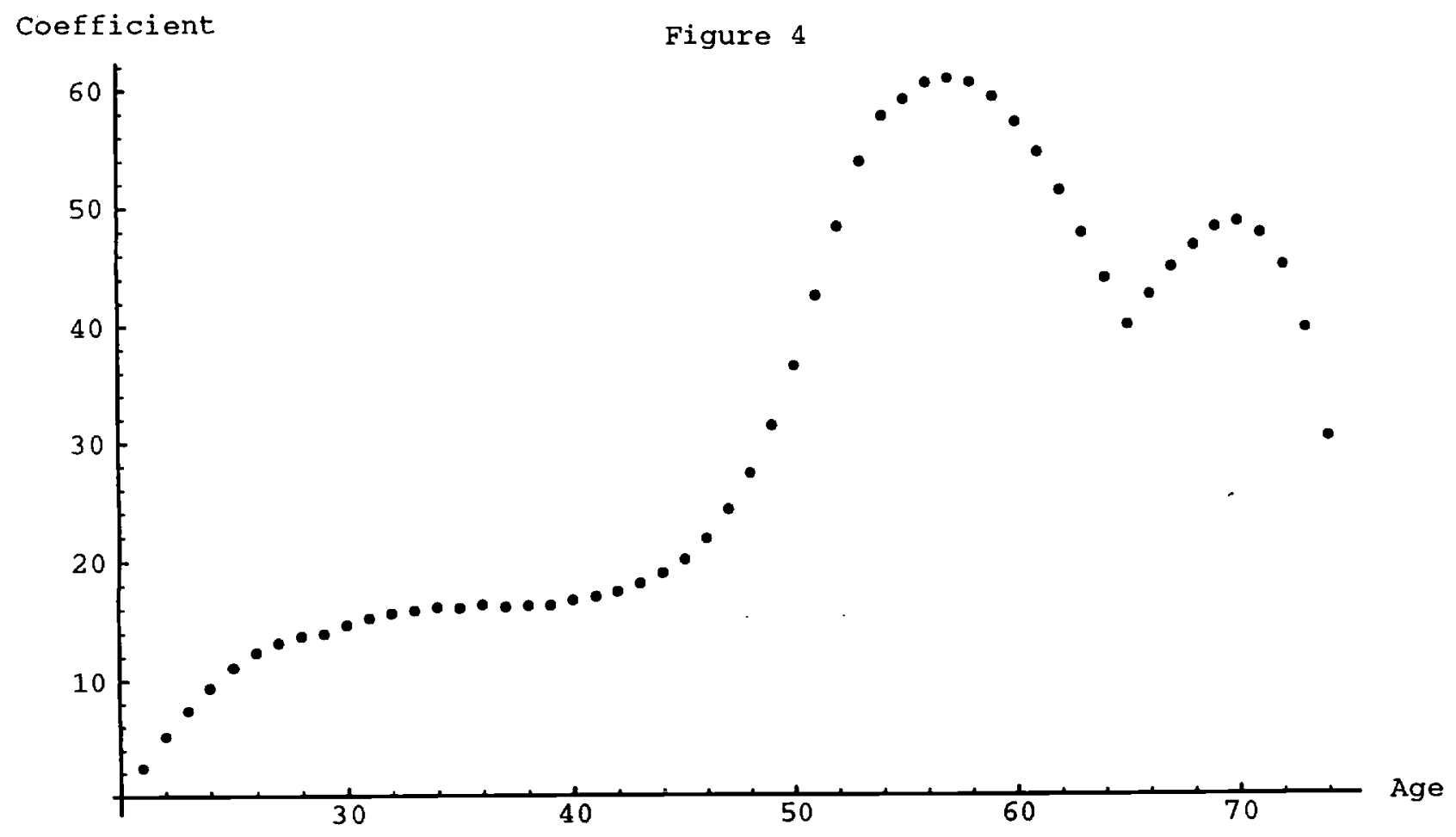




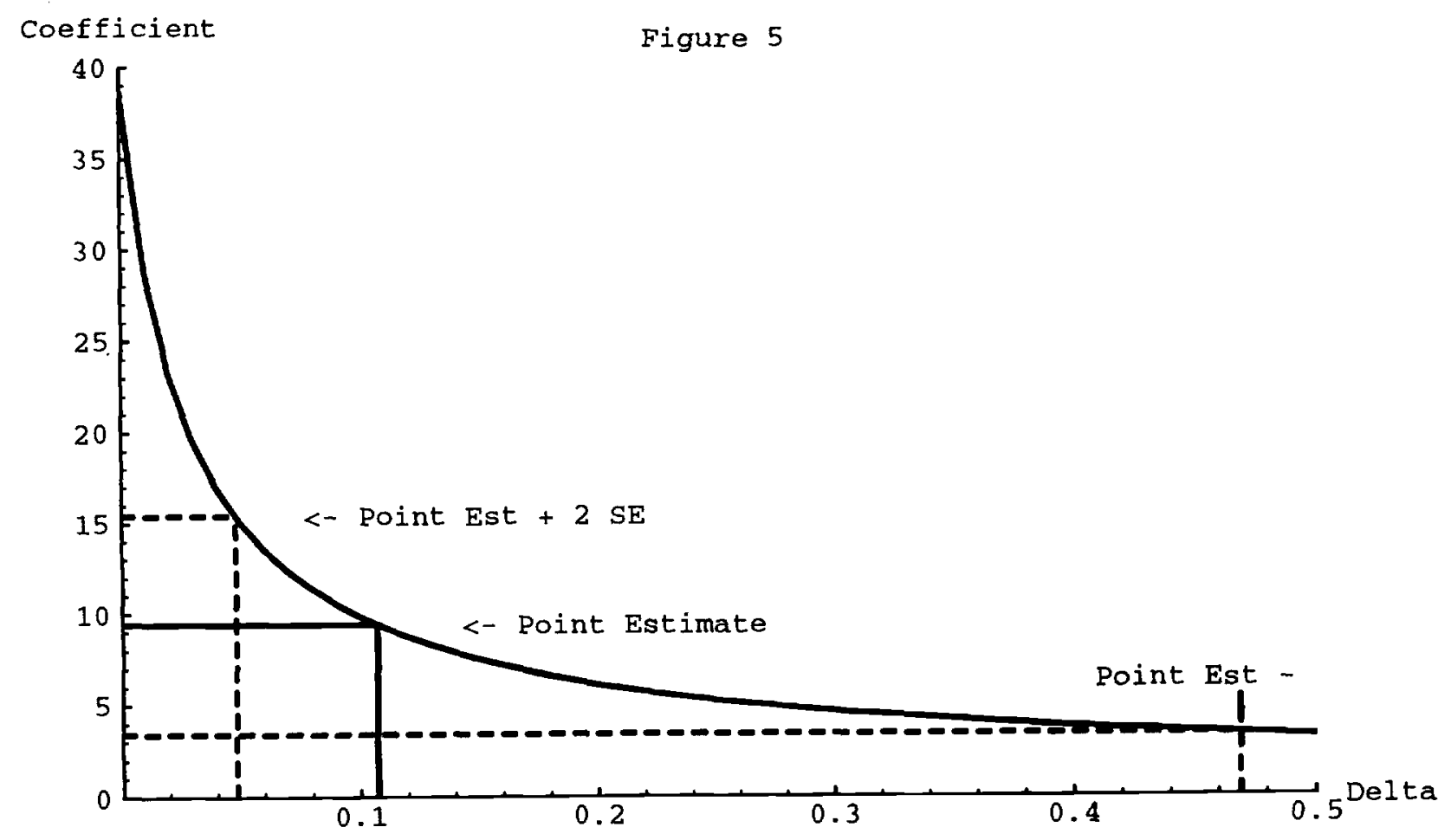

